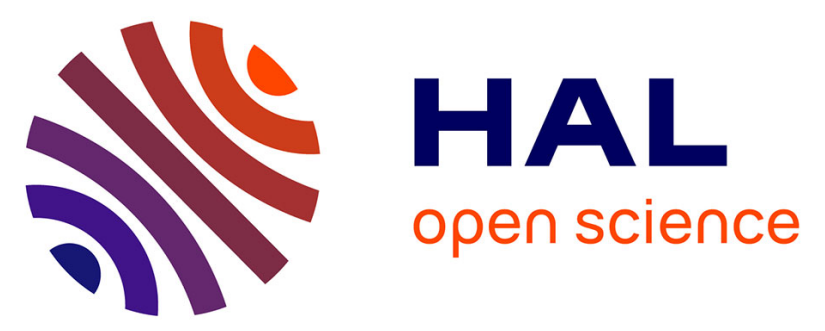

\title{
The proliferation of the toxic cyanobacterium Planktothrix rubescens following restoration of the largest natural French lake (Lac du Bourget)
}

S. Jacquet, Jf Briand, C Leboulanger, C Avois-Jacquet, L. Oberhaus, Bruno Tassin, Brigitte Vinçon-Leite, G Paolini, Jc Druart, O Anneville, et al.

\section{To cite this version:}

S. Jacquet, Jf Briand, C Leboulanger, C Avois-Jacquet, L. Oberhaus, et al.. The proliferation of the toxic cyanobacterium Planktothrix rubescens following restoration of the largest natural French lake (Lac du Bourget). Harmful Algae, 2005, 4 (4), pp.651-672. 10.1016/j.hal.2003.12.006 . hal-00711669

\section{HAL Id: hal-00711669 \\ https://hal-enpc.archives-ouvertes.fr/hal-00711669}

Submitted on 29 Mar 2015

HAL is a multi-disciplinary open access archive for the deposit and dissemination of scientific research documents, whether they are published or not. The documents may come from teaching and research institutions in France or abroad, or from public or private research centers.
L'archive ouverte pluridisciplinaire HAL, est destinée au dépôt et à la diffusion de documents scientifiques de niveau recherche, publiés ou non, émanant des établissements d'enseignement et de recherche français ou étrangers, des laboratoires publics ou privés. 


\title{
The proliferation of the toxic cyanobacterium Planktothrix rubescens following restoration of the largest natural French lake (Lac du Bourget)
}

\author{
Stéphan Jacquet ${ }^{\mathrm{a}, *}$, Jean-François Briand ${ }^{\mathrm{a}, \mathrm{b}}$, Christophe Leboulanger ${ }^{\mathrm{a}}$, \\ Carol Avois-Jacquet ${ }^{\mathrm{a}}$, Laura Oberhaus ${ }^{\mathrm{a}, \mathrm{c}}$, Bruno Tassin ${ }^{\mathrm{c}}$, Brigitte Vinçon-Leite ${ }^{\mathrm{c}}$, \\ Gérard Paolini ${ }^{\mathrm{d}}$, Jean-Claude Druart ${ }^{\mathrm{a}}$, Orlane Anneville ${ }^{\mathrm{a}}$, Jean-François Humbert ${ }^{\mathrm{a}}$ \\ a UMR CARRTEL, Equipe de Microbiologie Aquatique, Station INRA d'Hydrobiologie Lacustre, 74203 Thonon Cedex, France \\ b Laboratoire des Sciences de l'eau et de l'environnement, Faculté des Sciences, 87060 Limoges Cedex, France \\ ${ }^{\mathrm{c}}$ CEREVE, Ecole Nationale des Ponts et Chaussées, 77455 Marne La Vallée Cedex 2, France \\ ${ }^{\mathrm{d}}$ Cellule Technique de l'Aquarium du Bourget, 73100 Aix-les-bains, France
}

Received 15 August 2003; received in revised form 30 November 2003; accepted 6 December 2003

\begin{abstract}
Lac du Bourget, in the Alps, is the largest natural French lake. Following major restoration programmes during the 1970s and early 1980s, involving massive efforts to reduce nutrient loads and pollution in the lake, the water quality has improved over the past two decades. This can be inferred from the increase in the nitrate:phosphate ratio, the intensification of the "clear-water phase" (i.e. the increase in the water column transparency in spring), and the reduction in the total phosphorus and chlorophyll $a$ concentrations. However, blooms of the filamentous, phycoerythrin-rich, non-nitrogen fixing and hepatotoxic cyanobacterium Planktothrix rubescens have occurred since 1996 and have been maintained subsequently, at least during summer and autumn periods. Nutrients (especially phosphorus) are usually thought to be one of the most important factors responsible for cyanobacterial blooms, and so the question is asked if this bloom is a paradoxical outcome of the restoration programs? Using a large set of data taken from surveys of Lac du Bourget, from the literature, and from recent laboratory experiments, and also using field data for the neighboring Lake Geneva, we propose a realistic scenario to account for the population dynamics of the cyanobacterium and the occurrence and maintenance of the bloom in Lac du Bourget. The characteristics of the lake (high water column stability, deepening of the nutrient-depleted layer during the last decade, a long water residence time), local conditions (the nutrient load and charge) and global changes (global warming) all had to be taken into account to explain this bloom. We suggest that the success of P. rubescens in Lac du Bourget is probably due to increased transparency and a longer stratified period following (1) the restriction of other phytoplankton species following reduced phosphorus, which has allowed $P$. rubescens to make use of organic phosphorus to improve its competitiveness; (2) warmer than average winter/spring periods allowing an earlier water stratification and in fine a competitive advantage to $P$. rubescens; (3) lower than average surface irradiance, which has also given the low-light preferring P. rubescens an advantage. Finally,
\end{abstract}

\footnotetext{
* Corresponding author. Tel.: +334502678 12; fax: +33450260760.

E-mail address: jacquet@ thonon.inra.fr (S. Jacquet).
} 
this study highlights the importance of long-term data sets in attempting to elucidate the global causes of a major ecological problem (such as this cyanobacterial bloom) and impacts with regard to the function and use of freshwater ecosystems.

(C) 2004 Elsevier B.V. All rights reserved.

Keywords: Lake restoration; Global change; Cyanobacteria; Planktothrix rubescens; Bloom

\section{Introduction}

The large natural sub-alpine lakes (such as Lac du Bourget, Lake Geneva, Lake Garda, Lake Zürich, Lake Bodensee, etc.) constitute important drinking water resources, and major tourist attractions for several countries in Europe (France, Italy, Switzerland, Germany, Austria, etc.). During the second half of the 20th century, most of these lakes suffered from nutrient pollution, which led to a deterioration of their water quality (i.e. the suitability of water to sustain various uses or processes). One of the most harmful consequences of eutrophication, is the proliferation of microalgae and/or bacteria, including toxic cyanobacteria. This often leads to a reduction in biodiversity, leading to disruption of the trophic chain, a negative impact on the image of the lake, and possible problems for local fisheries as well as the potential toxic risks, to both animal and human health, as a result of drinking the water or swimming in it (Reynolds, 1987; Chorus and Bartram, 1999; Dokulil and Teubner, 2000; Briand et al., 2003). In order to improve the lake water quality, many attempts have been made to reduce the level of phosphorus, which is often the main limiting factor on phytoplankton growth processes in lakes (Sas, 1989; Anneville and Pelletier, 2000). These attempts, which have involved water treatment and the diversion of polluted water, have resulted in a reduction in the concentration of dissolved inorganic phosphorus. For example between 1980 and 2001, this level has fallen from 82 to $34 \mu \mathrm{g} \mathrm{l}^{-1}$ in Lake Geneva (the largest natural western European lake) and from 120 to $26 \mu \mathrm{g} \mathrm{l}^{-1}$ in Lac du Bourget. Despite this considerable reduction in the concentrations of phosphorus (and of nitrogen to a certain extent), proliferation of the cyanobacterium, Planktothrix rubescens, has interfered with the use of Lac du Bourget as a water supply for the human population since 1996. As already reported in German lakes (Fastner et al., 1999) and in Lake Zürich (Blom et al., 2001), P. rubescens in Lac du Bourget synthesizes high concentrations of microcystins
(Humbert et al., 2001), leading to a potential health hazard for the inhabitants of the surrounding cities, which draw on Lac du Bourget for drinking water.

As cyanobacteria are able to produce numerous toxins (hepatotoxins, neurotoxins, cytotoxins and lipopolysaccharide endotoxins), they can affect the structure and function of ecosystems as well as have an impact on animal and human health (Carmichael et al., 2001; Briand et al., 2003). Cyanobacteria are likely to have been responsible for the death of fishes (Rodger et al., 1994), wild birds (Matsunaga et al., 1999), cattle (Mez et al., 1997), dogs (Nehring, 1993) and human beings (Jochimsen et al., 1998). This has created an urgent need for a better understanding of the conditions favoring cyanobacterial growth, with the goal of providing a basis for the control and management of their occurrence and abundance (Chorus and Bartram, 1999). One of the planktonic cyanobacterial species is $P$. rubescens (Gomont) Anagnostidis and Komarek, 1988 (synonym Oscillatoria rubescens Gomont 1892), which proliferates in Lac du Bourget. This is a red-colored, filamentous cyanobacterium with gas vesicles, which is able to adjust its buoyancy and thus its position in the water column, in order to obtain its preferred low light environment (and possibly also in response to other resources). It often forms deep water maxima in the stratified lakes of temperate latitudes (Feuillade, 1994; Micheletti et al., 1998; Bright and Walsby, 2000; Humbert et al., 2001). Reynolds et al. (2002) describe it as an R-strategist.

In this study, we draw on a large data set (from 1984 to 2001) to provide an overview of the changes in the global and local parameters and processes affecting Lac du Bourget. This was then used to examine why $P$. rubescens populations have dominated the phytoplankton community for the last 7 years in Lac du Bourget, despite the fact that efforts to restore the lake have been in progress for more than 20 years, and have significantly reduced both $\mathrm{P}$ and $\mathrm{N}$ concentrations. 


\section{Materials and methods}

\subsection{Description of the site}

Lac du Bourget $\left(45^{\circ} 44^{\prime} \mathrm{N}, 231 \mathrm{~m}\right.$ altitude) is the largest natural French lake, and is located in the eastern part of France, on the edge of the Alps (Fig. 1). It is a warm, meromictic and elongated (18 and $3 \mathrm{~km}$ in length and width, respectively), north-south orientated lake, with an area of $42 \times 10^{6} \mathrm{~m}^{2}$, a total volume of $3.5 \times 10^{9} \mathrm{~m}^{3}$, maximum and average depths of 145 and $80 \mathrm{~m}$, respectively, and a water residence time of approximately 10 years. Winter overturn reaches the bottom of the lake only during very cold winters (Vinçon-Leite et al., 1995). It has a catchment area of about $560 \mathrm{~km}^{2}$, with maximum and average altitudes of 1845 and $700 \mathrm{~m}$, respectively. There are two important cities beside the lake: Chambery to the south and Aix-les-Bains to the east, with a combined population of 170,000 , plus a large influx of tourists $(+40,000)$ in the summer. Lac du Bourget has been suffering from eutrophication since 1950 . Water quality restoration programs started in the 1970s. These programs involved the development and/or improvement of waste water treatment plants and, in 1981, the diversion of the treated sewage from the two main cities (Cham-

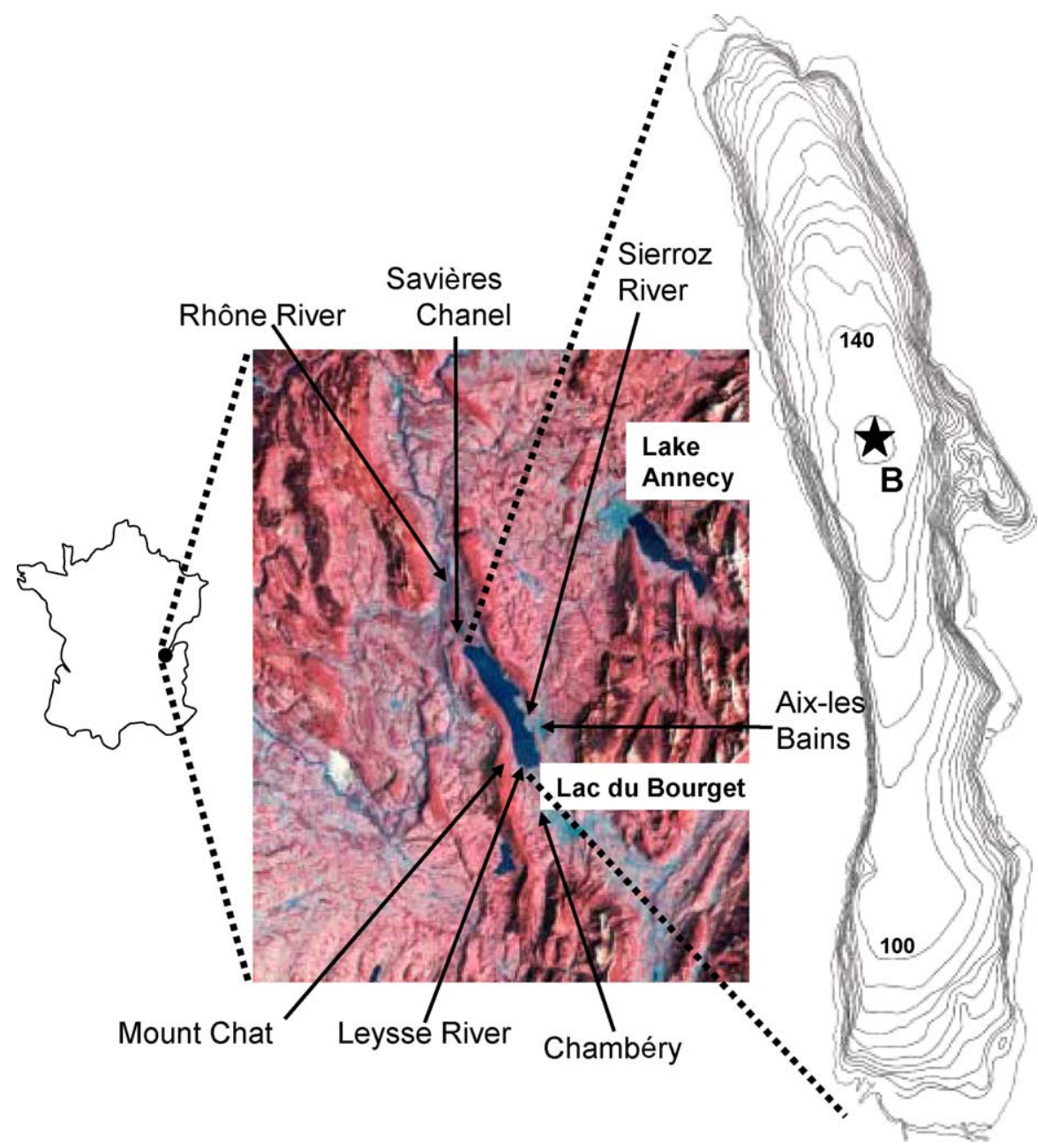

Fig. 1. Lac du Bourget and its catchment area. See Section 2 for further details. 
béry and Aix-les-Bains) into the Rhône River through a tunnel under Mount Chat. Other improvements of the functioning of the sewer system-especially the control of the combined sewer overflows-lead in the recent years to an additional reduction of the nutrient loading to the lake. Two rivers, the Leysse and the Sierroz, are the main freshwater inputs to the lake, with average flow rates of 8.5 and $3.5 \mathrm{~m}^{3} \mathrm{~s}^{-1}$, respectively. The flow rates of these two rivers can occasionally (during floods for instance) reach more than 120 and $30 \mathrm{~m}^{3} \mathrm{~s}^{-1}$, respectively. The outflow from the lake, located on its northern shore, is known as the Savière channel (length: $4.5 \mathrm{~km}$, mean flow rate: $10-30 \mathrm{~m}^{3} \mathrm{~s}^{-1}$, annual output: $0.5 \mathrm{~km}^{3}$ ) and it flows into the Rhone river (Fig. 1). Despite the importance of this lake, both in terms of its size and utilization (fisheries, drinking water supply and recreational activities), there have been only a few studies of the plankton ecology of this lake, and most of the literature has appeared as articles or reports in French (Leroux, 1928; Hubault, 1947; Bourrelly, 1949, 1955; Laurent, 1966; Balland, 1976; CEMAGREF reports, 1985, 1990; CEREVE report, 1998). Only recently, have attempts been made to study phytoplankton variability and dynamics and to build predictive models of the water quality of Lac du Bourget (Vinçon-Leite et al., 1995, 2002; Tassin and Vinçon-Leite, 1998). During the last decade, in fact, most of the research on Lac du Bourget has been focused on its physical and geochemical functioning (e.g. Vinçon-Leite et al., 1989; Bournet et al., 1999; Groleau et al., 2000).

Lake Geneva is the largest natural lake in Western Europe. In the context of this study, data for this lake was only used for specific comparisons of the proliferation of $P$. rubescens, provided that the two lakes display very similar nutrient concentrations and evolution since the early 1990's, and are subjected to similar climatic conditions. Further information about Lake Geneva can be found elsewhere (e.g. Anneville et al., 2002, http://www.cipel.org).

\subsection{Sampling locations}

Since 1984, Lac du Bourget has been surveyed by regular monitoring of water transparency, chlorophyll $a$ concentration and occasionally other basic parameters such as nutrients and phytoplankton. All the data presented in this paper correspond to sampling performed at the reference station located in the middle and deepest part of the lake, referred to as point $\mathrm{B}$ (Fig. 1). This station is more than $1.5 \mathrm{~km}$ from each bank and more than 5 and $10 \mathrm{~km}$ from the Sierroz and Leysse rivers, respectively. For Lake Geneva, the data were also obtained from the reference point of the lake, referred to as SHL2, located more than $6 \mathrm{~km}$ from the nearest shore.

\subsection{Meteorological data}

Data such as air temperature, wind force and direction, irradiance, cloudiness and precipitation were obtained at a $3 \mathrm{~h}$ time step from the meteorological station Voglans at Chambéry airport, located less than $1 \mathrm{~km}$ from the southern shore of Lac du Bourget. The meteorological data for Lake Geneva were obtained from the INRA laboratory in Thonon. The North Atlantic Oscillation (NAO) winter index (December-March), which provides an index of the large-scale natural climate variability with a major impact on the weather and climate in the North Atlantic region and surrounding continents, was obtained at http://cdg.ucar.edu/ jhurrell/nao.pc.nam.html.

\subsection{Data from the lake}

A conductivity-temperature-depth measuring device (CTD SEABIRD SBE 19 Seacat profiler) was used to obtain vertical profiles (from the surface to the bottom) of the water temperature. Oxygen concentration profile was determined using an oxygen probe (polarographic electrode YSI 5739). In this study, annual and/or seasonal mean values for temperature and oxygen concentration have been plotted for the depth $130 \mathrm{~m}$, i.e. $10 \mathrm{~m}$ above the bottom of the lake to follow the evolution of these parameters between 1984 and 2001 far from the surface, the latter being more sensitive to short-term (rainfall) and episodic (wind) climatic fluctuations, the influence of diel variations, biology, etc. The temperature at between 0 and $15 \mathrm{~m}$ was reported as the annual deviation (or anomaly) from the average value over the time series. Temperature data were also used to determine the onset of water column stratification. We assumed that stratification had occurred when there was a temperature differential of more than $1{ }^{\circ} \mathrm{C}$ between the 2 and 
$130 \mathrm{~m}$ depths on two consecutive sampling dates. The Brunt-Väisälä frequency (which measures the natural frequency of oscillation of a vertical column of water, and can be viewed as an index of the water column stability, Lemmin, 1978) was also calculated from the temperature values, according to the following equation:

$N^{2}=\frac{g}{\rho}\left(\frac{\mathrm{d} \rho}{\mathrm{d} z}\right)$

where $N^{2}$ is the stability coefficient (in $\mathrm{s}^{-2}$ ), $g$ the acceleration parameter (in $\mathrm{m} \mathrm{s}^{-2}$ ), $\rho$ the water density (no unit), $z$ is the depth (in meter)

with : $\quad \rho(T)=1000-7 \times 10^{-3}(T-4)^{2}$

according to Lemmin (1978), where $T$ is the temperature (in ${ }^{\circ} \mathrm{C}$ )

Nutrient concentrations (total phosphorus, $\mathrm{P}-\mathrm{PO}_{4}$, total nitrogen, $\mathrm{N}-\mathrm{NO}_{3}, \mathrm{~N}-\mathrm{NH}_{4}, \mathrm{SiO}_{2}$ ) were measured at the INRA Hydrobiological Station according to French procedures and protocols (AFNOR, 1982). The mean annual values corresponding to average winter overturn concentrations measured at 2, 15, 130 and $140 \mathrm{~m}$ were examined for the period 1984 to 2001. In addition, the total nutrient input into the lake from the two main rivers (the Sierroz and the Leysse) was assessed in 1974, before the diversion of the waste water, and three times over the 1983-2001 period. The corresponding calculated loads are reported. To assess the P-depletion in the mixed surface layer, a threshold $\mathrm{P}_{-} \mathrm{PO}_{4}$ value of $10 \mu \mathrm{gl}^{-1}$ was chosen during the clear-water phase (during the Spring) as in a previous study of Lake Geneva (Anneville and Pelletier, 2000), and following more general considerations concerning P-limitation for phytoplankton growth (Sas, 1989). Total $\mathrm{P}$ and $\mathrm{N}, \mathrm{P}_{-} \mathrm{PO}_{4}, \mathrm{~N}-\mathrm{NO}_{3}, \mathrm{SiO}_{2}$ were also measured at seven different depths between 0 and $50 \mathrm{~m}(2,6$, $10,15,20,30,50 \mathrm{~m})$ and sampled on average every 2 weeks. Values were examined for the year 2001.

Chlorophyll $a$ in unfiltered water was collected in the upper-lit layers according to the OECD, 1982 procedure (depth equal to 2.5-fold the Secchi depth, see below) using a Pelletier integrating bell (INRA patent, 1978). The concentration of chlorophyll $a$ was determined using the method of Strickland and Parsons
(1972). We examined both the mean and maximum annual values between 1987 and 2001, considering only the values corresponding to the same depth range.

Transparency data were obtained using a Secchi disk, and all measurements were performed by the same person throughout. Annual and monthly mean values were obtained between March and August from 1984 to 2001. Fig. 4G reports all the values obtained with a sampling frequency of 1 or 2 weeks during 2001. Assuming that the light intensity at the Secchi depth $\left(Z_{\mathrm{s}}\right)$, is $16 \%$ of the incident light intensity (Lemmin, 1978), the transparency data were also used to assess the euphotic depth $\left(Z_{\mathrm{eu}}\right)$, where the light is theoretically $1 \%$ of the surface intensity according to the following equation:

$Z_{\mathrm{eu}}=2.5 \times Z_{\mathrm{s}}$

Underwater light (PAR) intensity, from the surface to a depth of approx. $30 \mathrm{~m}$, was measured only occasionally in 2002, using a LI-1400 current meter and data logger combined with a spherical quantum sensor LI-193SA (LI-COR, Lincoln, Nebraska, USA). It is noteworthy that the theoretical value of 2.5 was verified from several in situ measurements during the year 2002 (Jacquet, unpublished).

When samples were available, the phytoplankton species, were identified and counted according to Uthermöhl (1958). No phytoplankton quantitative data were available for the period between 1982 and 1994. For $P$. rubescens, the cell number was estimated by counting $200 \mu \mathrm{m}$ length filaments and by assuming a mean cell length of $5 \mu \mathrm{m}$. Several vertical profiles of the main phytoplankton groups, including $P$. rubescens, and of the temperature were also obtained using a submersible spectrofluorimeter (BBE-Fluoroprobe, Germany). This in situ measuring/recording device, which can be used to perform chlorophyll $a$ analysis and integrated algal class determination, has been shown to provide a realistic estimation of the abundance and dynamics of the cyanobacterial population (Leboulanger et al., 2002). Phytoplankton biomass, species richness and succession patterns for Lac du Bourget and Lake Geneva were obtained for the period 1995-1996, corresponding to some detailed analyses of phytoplankton communities in these two lakes for the same periods (Table 1). 
Table 1

Comparative description of the main phytoplankton species recorded in Lakes Geneva and Bourget in 1995 and 1996

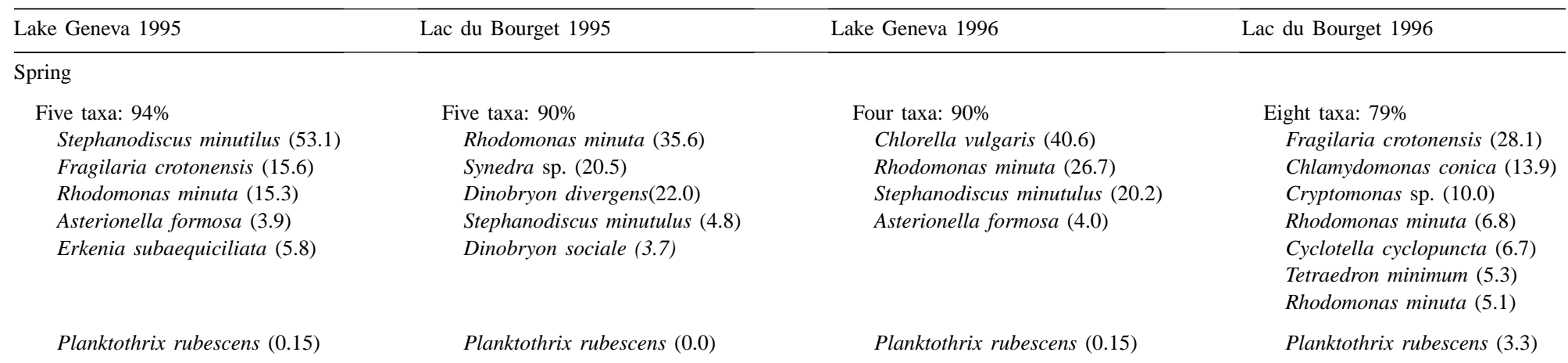

\section{Summer}

Five taxa: $86 \%$

Rhodomomas minuta (50.0)

Cyclotella cyclopuncta (21.9)

Asterionella formosa (9.7)

Dinobryon divergens (4.9)

Cryptomonas sp. (3.2)

Planktothrix rubescens $(0.08)$

\section{Eight taxa: $84 \%$}

Achnanthes catenata (29.8)

Mougeotia gracillima (23.8)

Tribonema ambiguum (6.6)

Tabellaria flocculosa (6.6)

Rhodomonas minuta (3.6)

Fragilaria crotonensis (3.5)

Aphanizomenon flos aquae (3.3)

Oscillatoria limnetica (7.0)

Planktothrix rubescens (0.1)

Fall

Nine taxa: $88 \%$

Diatoma elongatum (24.6)

Mougeotia gracillima (17.9)

Rhodomonas minuta (13.6)

Cyclotella cyclopuncta (11.8)

Chlorella vulgaris (7.6)

Pseudanabena galeata (4.0)

Fragilaria crotonensis (2.9)

Erkenia subaequiciliata (3.3)

Planktothrix rubescens (2.8)
Three taxa: $88 \%$

Tabellaria flocculosa (69.9)

Rhodomonas minuta (11.5)

Fragilaria crotonensis (6.6)

Planktothrix rubescens (1.3)
Nine taxa: $90 \%$

Erkenia subaequiciliata (24.2)

Mougeotia gracillima (22.7)

Rhodomomas minuta (12.6)

Fragilaria crotonensis (10.0)

Ochromonas sp. (5)

Oscillatoria limnetica (4.2)

Chlorella vulgaris (3.3)

Diatoma elongatum (3.2)

Flagellés sp. (3.0)

Planktothrix rubescens (0.0)

Eight taxa: $89 \%$

Diatoma elongatum (34.6)

Mougeotia gracillima (15.6)

Rhodomonas minuta (12.6)

Chlorella vulgaris (12.1)

Erkenia subaequiciliata (3.9)

Ochromonas sp. (3.8)

Pseudabaena galeata (3.8)

Dinobryon sociale (2.7)

Planktothrix rubescens (1.2)
Six taxa: $83 \%$

Mougeotia gracilima (38.5)

Tribonema ambiguum (8.9)

Achnanthes catenata (7.4)

Closterium aciculare (3.5)

Fragilaria ulna var. acus (2.6)

Planktothrix rubescens (22.4)

Six taxa: $70 \%$

Chlamydomonas conica (26.7)

Dinobryon sociale (4.2)

Ceratium hirundinella (4.9)

Stephanodiscus minutulus (4.9)

Cyclotella cyclopuncta (4.3)

Planktothrix rubescens (24.7) 
Winter

Six taxa: $92.5 \%$

Rhodomonas minuta (23.3)

Chlorella vulgaris (7.9)

Cyclotella cyclopuncta (5.9)

Diatoma elongatum (5.9)

Cyclotella radiosa (4.5)

Planktothrix rubescens (2.7)
Two taxa: $92 \%$

Tabellaria flocculosa (89)

Cryptomonas sp. (3.5)
Six taxa: $87 \%$

Rhodomonas minuta (10.3)

Rhodomonas minuta (3.9)

Cryptomonas sp. (3.8)

Aphanizomenon flos aquae (3.8)

Planktothrix rubescens (10.3)
Eight taxa: $87 \%$

Tabellaria flocculosa (62.8)

Melosira varians (5.1)

Planktothrix rubescens (7.9)

Planktothrix rubescens (20.5)

The relative importance of $P$. rubescens is also shown. The number in parentheses corresponds to the percentage relative importance of the species in terms of cell numbers.

For filamentous cyanobacteria, cell numbers were estimated from measurements of $100 \mu \mathrm{m}$ length filaments. During these years, the total number of taxa recorded was almos the same in the two lakes, i.e. about 124 and 127-144 for lakes Bourget and Geneva, respectively. Note that the 2 years were very different in terms of phytoplankton succession and dominance. 


\section{Results}

\subsection{Changes in physical parameters}

Both the winter and spring air temperatures measured on the southern shore of the lake have increased during the last 20 years, whereas no clear trend was observed for the other two seasons (Fig. 2A). The air temperature during the winter season has increased by almost $2-3^{\circ} \mathrm{C}$ from the early 1980 s to the present. As a consequence, the water temperature of the lake has also risen, and this has been particularly striking, with a change in both the bottom (Fig. 2B) and surface water temperatures measured over the same winter period (Fig. 2C). The warmest year during the last decade, until 2001, was 1996. The onset of water column stratification (Fig. 2D) has occurred earlier and earlier during the last 20 years (it now occurs almost 3 weeks earlier), and stratification now lasts longer. Another consequence of global warming has been a reduction in the winter overturn of the water column. This could be inferred from both the temperature profiles and the evolution of the oxygen concentration in the bottom part of the lake (Fig. 2E). Indeed, a clear negative relationship $(r=-0.6, n=18$, $P<0.01$ ) between bottom temperatures and oxygen concentrations during the winter has been observed. Whatever the season, the concentration of oxygen in the hypolimnion has fallen, on average from 8.3 to $3.2 \mathrm{mg} \mathrm{l}^{-1}$ between 1984 and 2001. However, it should be noted that the mean oxygen concentration increased in some years. Other physical parameters, such as the total irradiance or rainfall, also showed some particular patterns, and, during the last two decades, there has been a higher level of cloud cover and precipitation, and less light now reaches the lake.

\subsection{Change in nutrient concentrations and phytoplankton-related parameters}

From 1984 to 2001, N-NO 3 and $\mathrm{P}^{-\mathrm{PO}_{4}}$ concentrations fell from 750 to $600 \mu \mathrm{gl}^{-1}$ and from 100 to $30 \mu \mathrm{gl}^{-1}$, respectively (Fig. $3 \mathrm{~A}$ and B), as a consequence of restoration programs. Since the mid 1990 s, the level of phosphorus has remained relatively constant at around $30 \mu \mathrm{gl}^{-1}$. From 1974 to
1996, total $\mathrm{P}$, phosphate, total $\mathrm{N}$ and nitrate inputs from the two main rivers have fallen from 300 to 94 tonnes per year, 140 to 18 tonnes per year, 1800 to 450 tonnes per year and 1500 to 450 tonnes per year, respectively. The change in the $\mathrm{N}-\mathrm{NO}_{3}: \mathrm{P}_{-} \mathrm{PO}_{4}$ ratio from 1984 to 2001 also revealed the improvement in water quality that has risen from approximately 7 to 20, that suggests $\mathrm{P}$ has a more important role in terms of plankton limitation (Fig. 3C). Note that the same trend was found for total $\mathrm{P}$ and total $\mathrm{N}$ (not shown). This increase in the N:P ratio also reveals that nutrient-reducing efforts have focused on phosphorus. What may be more informative is the change in the $\mathrm{P}_{-} \mathrm{PO}_{4}$ concentration in the surface mixed layer, as inferred from Fig. 3D. During the last two decades, a marked deepening of the P-depleted layer has been recorded following the 'spring bloom' and this has contributed to important consequences for the plankton ecology, especially the bloom dynamics of $P$. rubescens. This deepening was greatest in 1996. The impact of nutrient reduction can be observed on both the chlorophyll $a$ concentration and transparency. Chlorophyll $a$ concentrations measured between 1987 and 2001 reveal a significant decrease in both the annual mean (more than 20\%) and annual maximum (more than $40 \%$ ) values (Fig. 3E). It is worth noting that for February and March the amount of chlorophyll $a$ sampled throughout the same water column at the same point (i.e. from the surface to $20 \mathrm{~m}$ ) increased significantly during the survey period (from 1.3 to $3.5 \mu \mathrm{g}^{-1}$ on average) suggesting a direct (warming) and/or indirect (earlier stratification) impact of temperature (and also light) on phytoplankton development.

On an annual scale basis, there was no clear increase in water transparency (Fig. 3F), with average values close to $6 \mathrm{~m}$. However, by selecting key periods of the year, between the end of winter (March) and early summer (July), we observed definite changes in the water transparency, specifically, there was a major increase in water transparency for the May period, suggesting the development/intensification throughout the re-oligotrophication process of the "clear-water phase" (Fig. 3F). Similarly, since the first evidence was found of the major development of $P$. rubescens in summer in Lac du Bourget, in 1996 (Table 1), chlorophyll $a$ has increased, whereas transparency has decreased. 

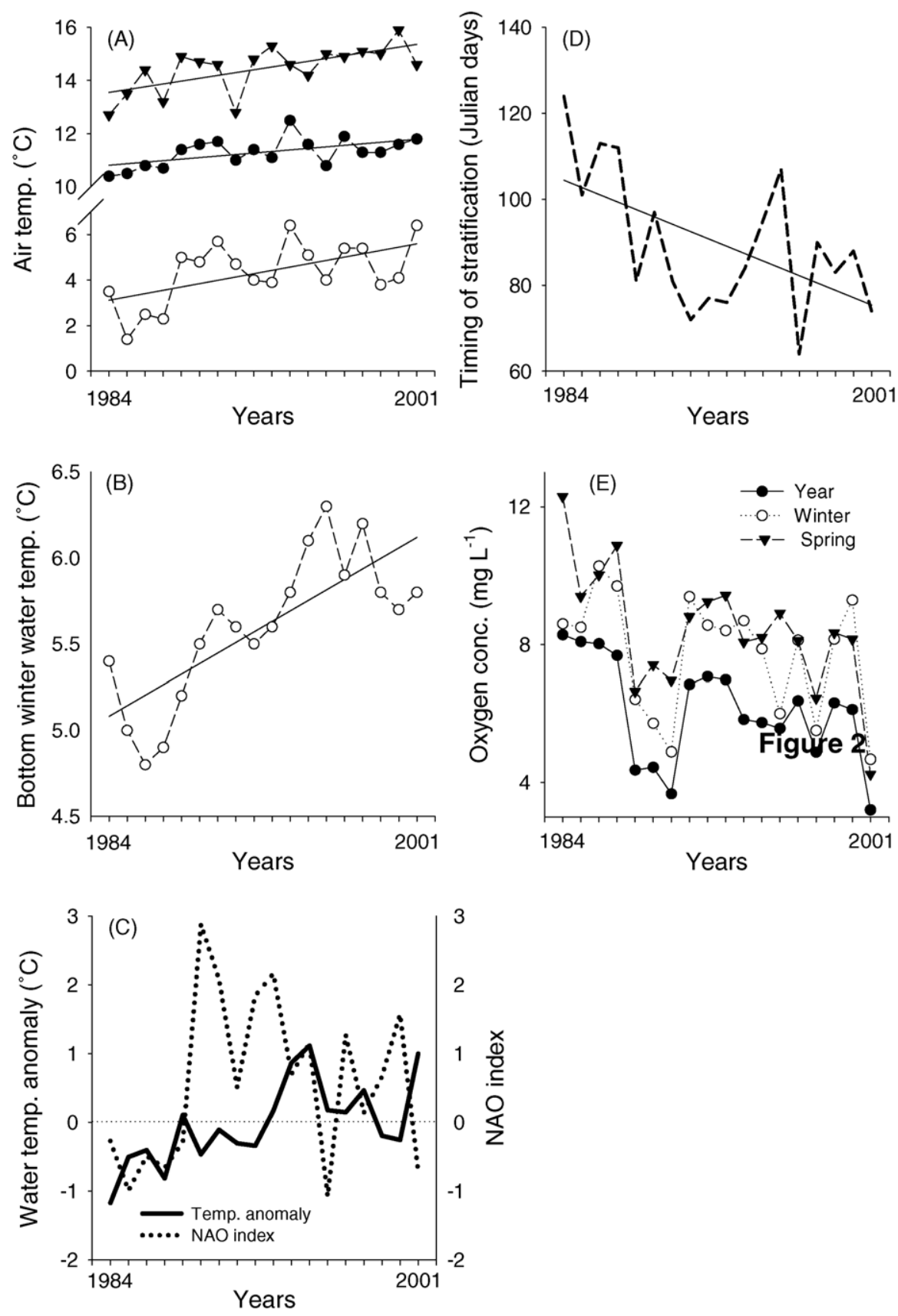

Fig. 2. A: Mean seasonal and annual air temperatures from 1984 to 2001 (data courtesy of the meteorological station Volgans, Chambéry). B: Data sets of the winter bottom water temperature $(130 \mathrm{~m})$ from 1984 to 2001. C: Deviation of the mean winter water temperature (December-March) from the long-term annual mean for 1984-2001 (black line) and the winter NAO index (dotted line). D: Timing of the onset of stratification from 1984 to 2001 based on temperature data. E: Data sets of the mean seasonal and annual oxygen concentration at a depth of $130 \mathrm{~m}$ from 1984 to 2001. For panels A, B and E, symbols are as follows: $(\boldsymbol{O})$ year; $(\bigcirc)$ winter; and $(\boldsymbol{\nabla})$ spring. 

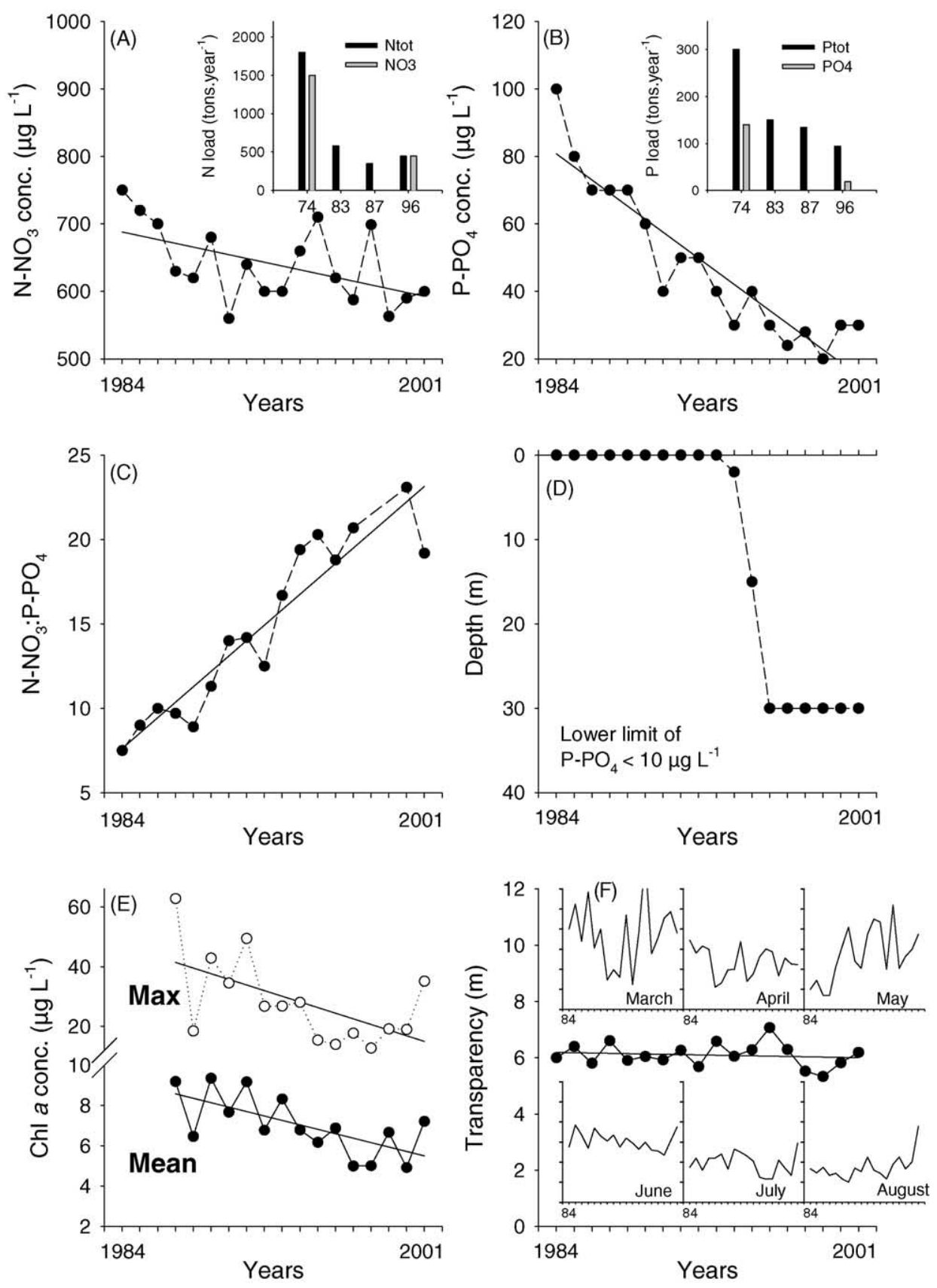

Fig. 3. $\mathrm{N}_{-\mathrm{NO}_{3}}$ (A) and $\mathrm{P}_{-} \mathrm{PO}_{4}$ (B) concentrations from 1984 to 2001. Each value corresponds to an annual mean calculated at depths of 2, 15,130 and $140 \mathrm{~m}$. The change in the total $\mathrm{N}$ and $\mathrm{P}$ external load (Leysse + Sierroz) at selected dates is also shown in inserts. C: Change in the $\mathrm{N}-\mathrm{NO}_{3}: \mathrm{P}_{-} \mathrm{PO}_{4}$ ratio from 1984 to 2001. D: Depth of the mixed layer with depleted dissolved inorganic phosphorus (concentrations below $10 \mu \mathrm{g}^{-1}$ ) during spring. E: Mean and maximum values of chlorophyll $a$ concentration in the top $20 \mathrm{~m}$ layer from 1987 to 2001 . F: Change in the annual and selected monthly mean values obtained for transparency between 1984 and 2001. 


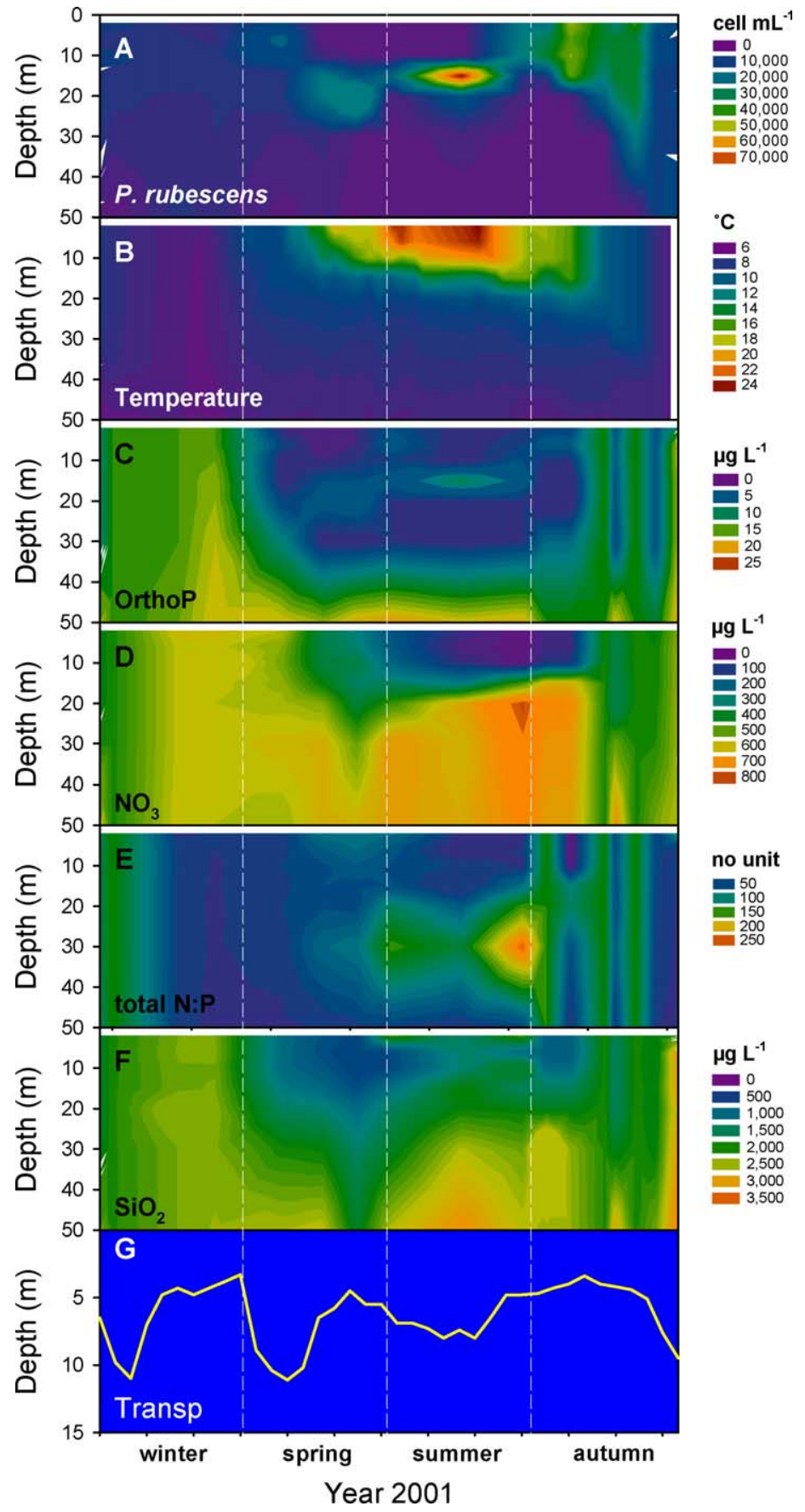

Fig. 4. Data sets for P. rubescens cell concentration (A), water temperature (B), phosphates (C), nitrates (D), the total N:P ratio (E), silicates (F) and water transparency (G) over $0-50 \mathrm{~m}$ in 2001. 


\subsection{Population dynamics of P. rubescens}

The same annual pattern of change measured by both the fluorescence probe measurements and the conventional microscopic cell counts of $P$. rubescens was found throughout the survey (Leboulanger et al., 2002). Fig. 4 shows the dynamics of $P$. rubescens as well as of the other main factors recorded over 1 year (2001), as an example of what has been regularly observed between 1998 and 2001. The initiation of the bloom began in late spring with a peak of cell density recorded during summer at the border between the epilimnion and the metalimnion (Fig. 4A). This was recorded (i) while lake thermal stratification occurred, as inferred from water temperature profile (Fig. 4B); (ii) when $\mathrm{P}_{-} \mathrm{PO}_{4}$ and $\mathrm{N}-\mathrm{NO}_{3}$ nutrients were depleted in the euphotic zone (Fig. 4C and D); and (iii) following the clear-water phase, as inferred from the maximal water transparency values of end April, early May (Fig. 4F). The peak concentration of the cyanobacterium reached approximately $80 \times 10^{3}$ cells $\mathrm{ml}^{-1}$, and throughout the summer, most of the biomass was concentrated close to the thermocline (Fig. 4A and B), at depths between 10 and $15 \mathrm{~m}$. At these depths, the light ranged from 4 to $60 \mu \mathrm{mol}$ quanta $\mathrm{m}^{-2} \mathrm{~s}^{-1}$ depending on cloud cover (not shown). In a $36 \mathrm{~h}$ survey, in which measurements were made every $2 \mathrm{~h}$, we could detect diel vertical migrations of the filaments during this period (Groleau et al., unpublished). By the end of summer/early autumn, before destratification of the water column, filaments were observed in the upper water column (Fig. 4A), suggesting that the Planktothrix population had moved upwards. When destratification occurred during the autumn-winter, as the thermocline started to erode and the mixed layer expanded in response to lower temperatures and increased wind stress, the filaments were mixed almost uniformly down to the lake bottom. During this period, the population density fell. $P$. rubescens remained present at relatively high concentrations in the upper lit layer during the autumn (up to $50 \times 10^{3}$ cells $\mathrm{ml}^{-1}$ ) and winter (up to $20 \times 10^{3}$ cells $\mathrm{ml}^{-1}$ ), and was probably still biologically active (e.g. Micheletti et al., 1998; Bright and Walsby, 2000). It is noteworthy that the bloom of $P$. rubescens was strongly associated with intracellular toxin production, especially microcystin demethyl RR $(r=0.66, n=160, P<0.01$, not shown) that sometimes reached concentrations consid-

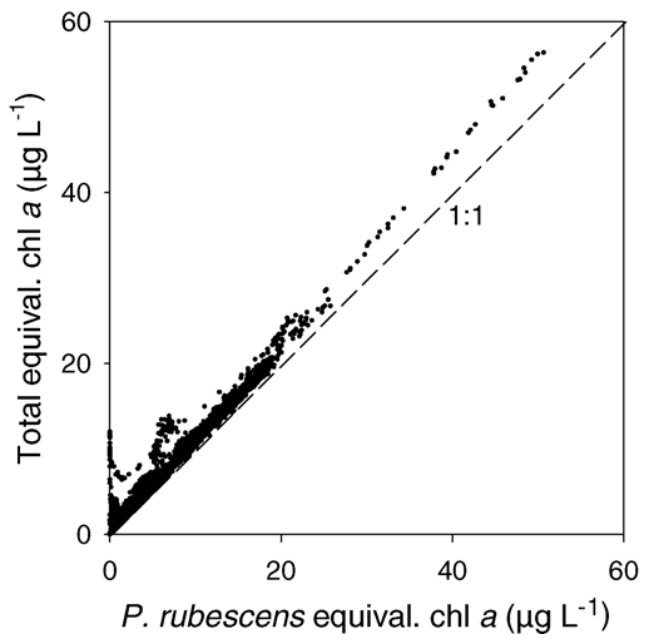

Fig. 5. Relationship between the total equivalent chlorophyll $a$ and $P$. rubescens concentration measured using a Fluoroprobe from all the profiles obtained during $2001\left(y=1.07 x+0.44, r^{2}=0.97\right.$, $n=5681)$. The dashed line indicates the 1:1 relationship. $P$. rubescens is the major phytoplankton responsible for the bulk of chlorophyll $a$ fluorescence throughout the year. Most of the data are above the 1:1 relationship, suggesting that the cyanobacterium is not the only autotroph. Above approx. $15 \mu \mathrm{g} \mathrm{l}^{-1}$ of total equivalent chlorophyll $a$, the fluorescence is solely attributable to cyanobacteria populations (mainly $P$. rubescens and to a lesser extent Pseudanabaena galeata and Oscillatoria limnetica that display peak cell concentrations at the same depth as $P$. rubescens). Below this $15 \mu \mathrm{gl}^{-1}$ value, some eukaryotic phytoplankters including the Bacillophyceae, Chlorophyceae and Cryptophyceae may contribute significantly to the total chlorophyll fluorescence in the upper lit layer during the spring and summer months.

erably above the drinking water guideline published by the World Health Organization of $1 \mu \mathrm{g} \mathrm{l}^{-1}$ in terms of equivalent microcystin LR (Briand et al., unpublished data). P. rubescens was therefore observed to be a perennial species accounting for more than $80 \%$ of the total chlorophyll $a$ fluorescence of the total phytoplankton biomass (Fig. 5, Leboulanger et al., 2002). Apart from P. rubescens, Bacillariophyceae (Asterionella formosa, Diatoma elongatum, Cyclotella cyclopuncta and Stephanodiscus sp.) and Cryptophyceae (Rhodomonas minuta) were the main groups responsible for the decreasing transparency in late winter-early spring; but this switched to the Cryptophyceae (R. minuta), Chrysophyceae (Dinobryon sp. and Ochromonas sp.), Bacillariophyceae (C. cyclopuncta) and Chlorophyceae (Chlorella vulgaris and Chlorelloidea sp.) in the autumn. 


\section{Discussion}

\subsection{Global change in Lac du Bourget since the 1950s}

Air and water temperatures have increased significantly during the last two decades, and Lac du Bourget has followed this general warming trend as a direct consequence of warmer winters and springs. This trend was also reinforced because of the occurrence of three very cold winters in the first years of the period under study. Before 1987 , temperatures below $5^{\circ} \mathrm{C}$ were regularly recorded in the lower parts of Lac du Bourget. It is a meromictic lake, and thus bottom layers are not involved every year in the mixing, as suggested by our data and previous reports (Vinçon-Leite et al., 1995). This phenomenon may have important consequences, since it could partly explain why the decline in nutrient concentrations has stopped; the depletion of oxygen in the bottom waters promotes the release of nutrients from sediments (Lemmin, 1978). Other studies have also demonstrated unambiguously that lake temperatures have risen significantly over recent decades for a set of European lakes, and this trend has been shown to be closely correlated with oscillations in the North Atlantic climate system, a major source of changes in weather and climate in the northern hemisphere with consequences on plankton phenology (Hurrel, 1995; Straile, 2000; Straile and Adrian, 2000; Sheffer et al., 2001; Weyhenmeyer et al., 1999; Anneville et al., 2002). A reduction in the vigour of the spring turnover implies that nutrients that have accumulated in the hypolimnion during the previous stratification period will not be uniformly distributed vertically throughout the whole water column. Because of these climate-dependent differences in nutrient upwelling from year to year, nutrient concentrations in the epilimnion of Lake Constance tend to be lower in high NAO years than in low NAO years, whereas the opposite is true of the hypolimnion (Straile et al., 2003). But up to now, this was not observed in Lac du Bourget and homogeneous profile of dissolved nutrients concentrations are always observed before the onset of the stratification.

With regard to the change in nutrient concentration, Lac du Bourget was considered as oligotrophic in the 1940s and 1950s (Hubault, 1943, 1947; Bourrelly, 1955). It underwent rapid eutrophication from the 1960s, and the total phosphorus concentration reached more than $120 \mu \mathrm{g} 1^{-1}$ in the early 1980s (Vinçon-Leite et al., 2002). Since the mid 1990s, nutrient concentrations have remained stable, which may be due in part to the high internal $\mathrm{P}$ load (with a release estimated to be up to 60 tonnes per year, CEREVE report, 1998) and the relatively long retention time of the ecosystem. In 2001, the total $\mathrm{P}$ concentration was about $26 \mu \mathrm{g} 1^{-1}$, so that, according to OECD criteria, Lac du Bourget was classified as a mesotrophic ecosystem. Concomitantly with the reduction of nutrients in the lake, the period during which the dissolved phosphorus in the top layers is depleted has become longer, and the depleted layer observed during the clear-water phase has extended deeper into the water column. In 1988, the P-depleted zone reached $15 \mathrm{~m}$ that is the thermocline depth (Vinçon-Leite, 1991). Since 1995, this P-depleted zone has reached 30-40 m, far beyond the thermocline. This metalimnic P-depletion was also observed in other lakes (Omlin et al., 2001; Anneville et al., 2002), and is probably attributable to $\mathrm{P}$ consumption by microorganisms and efficient adsorption of dissolved nutrients on reactive authigenic particulate material (Groleau et al., 2000).

At an annual scale, chlorophyll $a$ concentrations have fallen during the last two decades, following the considerable reduction of nutrients, especially P. However, the annual mean values for transparency have remained relatively stable. When considering selected periods of the year, however, the improvement in water quality was obvious with, for instance, intensification of the clear-water phase in May. What can be inferred from the changes in these two parameters during the period analysed is that the phytoplankton community and the population succession pattern have changed. In the 1950s, P. rubescens was reported to be relatively rare (Bourrelly, 1955), and Laurent (1966) reported a major proliferation of the green and filamentous alga Mougeotia gracillima in 1957. At the end of the 1960s, when the lake was definitely reported to be eutrophic, the phytoplankton consisted mainly of cyanobacteria including Aphanizomenon flos-aquae (40\%), and diatoms including Fragilaria crotonensis, Aulacoseira granulata and Melosira granulata (50\%). In October 1972, a surface bloom of both Microcystis aeruginosa and A. flos aquae was detected. During the 1983 survey, seven taxa of cyanobacteria were reported including three bloom formers: A. flos-aquae, M. aeruginosa and Microcystis wesenbergii. Other important 
species were M. gracillima and Tabellaria flocculosa (CEMAGREF report, 1985). During the detailed survey performed in 1995-1996 (see Table 1), 162 taxa were identified, including 13 species of cyanobacteria. Oscillatoria limnetica and A. flos-aquae were relatively important in 1995 , whereas $M$. aeruginosa had disappeared. Base on the available data, 1996 was the first year when $P$. rubescens became important $(22 \%)$. Previously considered to be an autumnal species, this cyanobacterium was observed at the end of spring-early summer. The other important species in 1995-1996 was M. gracillima also known as an autumnal species (Table 1). Reynolds (1980) pointed out that Asterionella, Fragilaria, Stephanodiscus, Endorina, Aphanizomenon, and Microcystis are good indicators of a eutrophic ecosystem, and that the situation may be worse if the two last species are replaced by P. rubescens. This is typically what happened in Lac du Bourget, with the apparent paradox that this development occurred in a context of re-oligotrophication.

\subsection{Why is $P$. rubescens now the dominant species in the phytoplanktonic community?}

Given the low light optimum reported for the growth of $P$. rubescens (see below), one of the most important processes involved in the $P$. rubescens development in Lac du Bourget seems to be the increasing transparency at selected periods of the year that has been recorded and that occurred earlier in the mid 1990s (Fig. 3F). Buergi and Stadelmann (2000) showed in Lake Boldegg that the dominance of $P$. rubescens was probably increased by the fact that the reduction of the nutrient supply increases transparency and thus the penetration of light into the metalimnion, where the cyanobacterium grows. Similarly, in Lake Nantua Feuillade and Druart (1994) reported that $\mathrm{P}$ reduction led to a reduction in filament concentration, and also the sinking of $P$. rubescens down to the metalimnion with, as a consequence, an increase of water transparency. More recently, Davis et al. (2003) also pointed out the importance of water column transparency as a main factor to consider for explaining the behavior of the Planktothrix population in Blelhalm tarn.

Obviously, the growth and vertical distribution of the $P$. rubescens population in Lac du Bourget is likely to be affected by many factors and/or processes. The
2001 survey revealed that nutrients displayed clearly different patterns. The depletion of $\mathrm{PO}_{4}$ and $\mathrm{SiO}_{2}$ began before that of $\mathrm{NO}_{3}$, and in addition, the depletion was deeper for both $\mathrm{P}$ and $\mathrm{SiO}_{2}$. The depletion of silicates was linked to the development of diatoms that were probably also responsible for the phosphorus depletion. The succession of phytoplankton species is known to play a key role, since nutrient depletion following the development of some of them will lead to the development of only very competitive species (Rocha et al., 2002; Salmaso, 2000). Very interestingly, $\mathrm{PO}_{4}$ depletion was recorded both above and below the bloom, whereas nitrate depletion occurred only in the upper part of the water column, above $P$. rubescens. The total $\mathrm{N}: \mathrm{P}$ ratio confirmed that phosphorus had been severely depleted when the bloom began.

How could $P$. rubescens bloom in a context of such low nutrient concentrations, especially of phosphorus? First of all, $P$. rubescens is able to excrete alkaline phosphatases, allowing it to use dissolved organic phosphorus when phosphates are depleted (Feuillade et al., 1990). In addition, the observation of complete depletion of nutrients may indeed occur on a large scale, depending on the sampling strategy, i.e. every 2 weeks. However, it is important to consider the potentially important role of heterotrophic bacteria and bacterivorous protozoa in nutrient remineralization, organic matter turnover from sinking material and the consequent growth of the cyanobacterium at a smaller time scale. This could partly account for the success of the species in low-nutrient conditions/layers with a relatively resource-rich microenvironment. This has been shown by Sheridan et al. (2002), who studied the microbial and metazoan community associated with colonies of the cyanobacterium Trichodesmium spp. In addition, the summer metalimnion may constitute a niche characterized by nutrient pulses, as a result of local mixing generated by water movements, such as internal waves (Thorpe, 1997; Hodges et al., 2000). Physical modelling of Lac du Bourget has recently shown that internal waves and fetch effects could be important and that horizontal inputs of nutrients from the littoral zone were more likely to occur than from the hypolimnion through the thermocline due to internal wave breaking (Bournet, 1996). Walsby and Schanz (2002) showed that low concentration of phosphate in the top $20 \mathrm{~m}$ of Lake Zürich 
suggest that $P$. rubescens accumulates most of the available phosphate before it is removed in autumn, and that it quickly removes pulses of phosphate delivered by mixing from deeper layers. They showed that nutrients did not limit $P$. rubescens growth during the stratification period, and that this may explain why the decrease in nutrient loading of Lake Zürich had so far little impact on population size (Walsby and Schanz, 2002). This is in agreement with our observations for Lac du Bourget, and also with the fact that 1996 was the first year when the P-depleted layer was so deep. Finally, P. rubescens has recently been shown to have photo-heterotrophic capacities (Zotina et al., 2003) giving this species an additional competitive advantage.

Light also appears to play a key role in the population dynamics of $P$. rubescens. We observed diel vertical migrations in the summer, and found that the Planktothrix population moved upwards before the autumn destratification, suggesting that this cyanobacterium can find its optimal niche in terms of light level. It is well known that $P$. rubescens is a cyanobacterium that can change its depth by buoyancy during summer stratification in response to changes in irradiance (Utkilen et al., 1985; Kromkamp and Walsby, 1990; Walsby et al., 2001; Walsby and Schanz, 2002) conferring a competitive advantage (Reynolds and Walsby, 1975; Reynolds et al., 1987). Recently, our laboratory experiments using isolates of $P$. rubescens from Lac du Bourget have demonstrated its growth aptitude for low and green light, i.e. at levels and wavelengths encountered at the depths where the population blooms occurred (Briand et al., unpublished data). Very interestingly, the surface solar irradiance has clearly decreased in recent years (between 1995 and 2000) compared to the average values recorded since the early 1980s, and this has also been shown to be directly correlated to the NAO variability. Low light conditions are thought to favor cyanobacteria, because these prokaryotes have lower maintenance costs than green algae (e.g. Olivier and Ganf, 2000). The advantage of low growth rates and the ability to grow at low irradiances have been discussed by Walsby and Schanz (2002): growth at low irradiances provides an advantage for filaments stratifying in the metalimnion in summer, for those entrained in the decreasing irradiance of autumn and for filaments circulating to greater depths during winter. The low maximum growth rate under low irradiance values may provide the benefits of lower nutrient requirements and better survival in oligotrophic situations. To grow at low irradiance, a filament must absorb a high proportion of the incident light; as a result of containing phycoerythrin pigments, P. rubescens is able to absorb green light (Feuillade, 1994), conferring wide spectral activity on this species and thus giving it a competitive advantage over microalgae and other cyanobacteria (Feuillade, 1994; Bright and Walsby, 2000, this study). Among the phytoplankton, cyanobacteria generally have the lowest growth rates (Raven, 1984), perhaps owing to the production costs of phicobilliproteins, which may account for up to $50 \%$ of the cell protein. P. rubescens has been reported to have the lowest growth rate for cyanobacteria (Bright and Walsby, 2000). Measurement of light in the field has always found irradiance levels below $60-80 \mu \mathrm{mol}$ quanta $\mathrm{m}^{-2} \mathrm{~s}^{-1}$ at the depth corresponding to the stratification of $P$. rubescens. This agrees with values reported in the literature, where it has been shown that $P$. rubescens growth can occur between 2 and $120 \mu \mathrm{mol}$ quanta $\mathrm{m}^{-2} \mathrm{~s}^{-1}$, with a maximum growth rate at around $26 \mu \mathrm{mol}$ quanta $\mathrm{m}^{-2} \mathrm{~s}^{-1}$ (Feuillade, 1994; Bright and Walsby, 2000; Vaughan et al., 2001; Davis et al., 2003). This ability to use low light has been measured directly in the field, but can also be deduced from the Zeu:Zm ratio, i.e. an index of the average underwater light climate. We showed that this ratio fluctuates over a narrow range in Lac du Bourget, around 0.9-1 on average, and that it has increased significantly during recent years (Fig. 6A). This is in agreement with Mur and Schreurs (1995) who showed that the stratifying species with Zeu:Zm (euphotic depth: mixed depth on the basis of the temperature profiles for the latter) ratios of between 0.7 and 1.2 can dominate the phytoplankton biomass. With this average light climate, the formation of large metalimnetic populations is possible, since light will repeatedly penetrate far enough to support the growth of these organisms. In comparison, the values for Lake Geneva have changed very differently, so that it is not impossible that light competition may play a critical role in the success of this species among comparable lakes (see below, Davis et al., 2003). Bright and Walsby (2000) have suggested that light limitation in late November could explain the cessation of $P$. rubescens growth in Lake Zürich. 

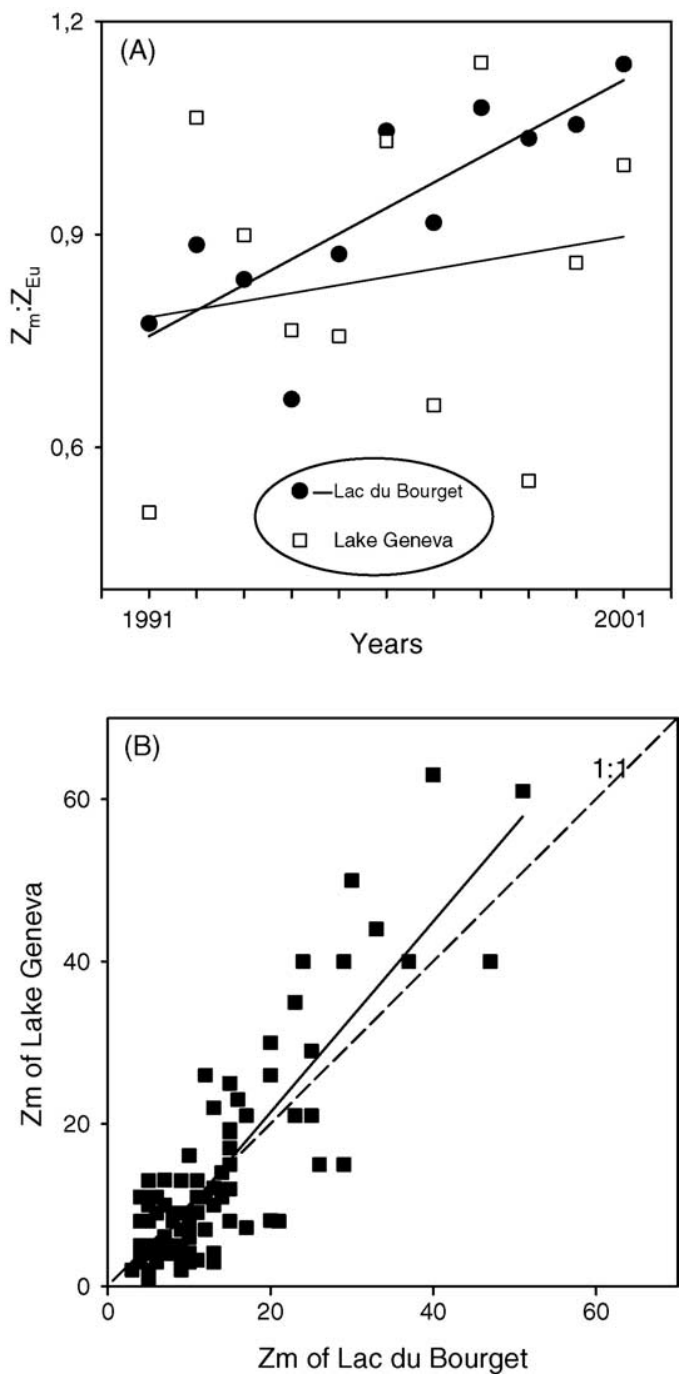

Fig. 6. A: Comparative changes in Lac du Bourget and Lake Geneva of the annual mean Zeu:Zm ratio between 1991 and 2001, when clear stratification was recorded in both lakes. B: Comparative data set for $\mathrm{Zm}$ for Lac du Bourget and Lake Geneva between 1991 and 2001 .

Another process controlling the development of a cyanobacterium such as $P$. rubescens is wind speed and water column hydrodynamics. We have shown, in agreement with previous studies, that the population only develops when water column stratification has been established (Humbert et al., 2001; Walsby and Schanz, 2002). Our data confirmed that the earlier onset water column stratification was followed by the development of $P$. rubescens. We will discuss the importance of this process below when we compare Lac du Bourget and Lake Geneva to find out why both the stratification and light climate are likely to explain why $P$. rubescens is dominant in Lac du Bourget but not in Lake Geneva.

Although we cannot present any data concerning top-down effects on P. rubescens, our preliminary laboratory experiences also suggest that this cyanobacterium is poorly grazed (Avois-Jacquet et al., unpublished data). Microcystin production by $P$. rubescens seems to be implicated in this resistance to grazing (Blom et al., 2001, Avois-Jacquet, unpublished data). In addition, the cyanobacterium is probably rarely subject to viral attack (Jacquet, unpublished data). These findings are in agreement with recently published studies (Kurmayer and Juttner, 1999; Suttle, 2000), which have shown that this low top-down or side effect may also explain cyanobacterial bloom development and maintenance.

\subsection{Lac du Bourget versus Lake Geneva}

Why has $P$. rubescens been blooming every year in Lac du Bourget but not in Lake Geneva, even though the nutrient status and the phytoplankton richness are very similar in these two ecosystems? Differences have been recorded in terms of the dominating phytoplankton species, with $P$. rubescens dominating in Lac du Bourget, but other species dominating in Lake Geneva (Mougeotia gracillima in 1999, Tabellaria flocculosa in 2000, which are both relatively low velocity sinkers and resistant to grazing). The species richness of the lakes can be explained by their frequent disturbance by wind and wave actions that allow many species to coexist (Padisak et al., 1993). Lake Geneva is larger and more strongly affected by these two processes than Lac du Bourget. In addition, Lake Geneva has more extensive areas of shallow littoral waters, and these areas are known to be potential inoculation zones for many algae. However, the only comparable data available for the period 1995-1996 revealed a total microphytoplankton species diversity of about 144 species for Lake Geneva and 162 for Lac du Bourget. Since 1990, the number of species in Lake Geneva has never exceeded 151 (Druart, unpublished data). In addition, recent flow cytometric analyses of pico- and nanophytolankton over one complete year did not reveal significant differences 
between the two lakes (Jacquet, unpublished data). It is thus tempting to argue that one of the main factors accounting for the greater bloom development and maintenance of $P$. rubescens in Lac du Bourget than in Lake Geneva, is the water column stability. It is well known that changes in the species composition reflect critical changes in the environment, particularly changes connected with the stability of the water column (e.g. Harris, 1986; Salmaso, 1996) that may influence other parameters, such as light availability (and nutrient inputs, sinking rates of cells, etc.). From our data, we can see that the mixing layer $(\mathrm{Zm})$ in Lake Geneva is greater, leading to a deeper thermocline, and suggesting that on average Lac du Bourget received more light at the epi-metalimnion boundary (Fig. 6B). Water column stratification has been shown to be advantageous to many harmful algal bloom species, including freshwater cyanobacteria such as Nodularia, Aphanizomenon, and Planktothrix, and marine dinoflagellates such as Alexandrium, Dinoph-
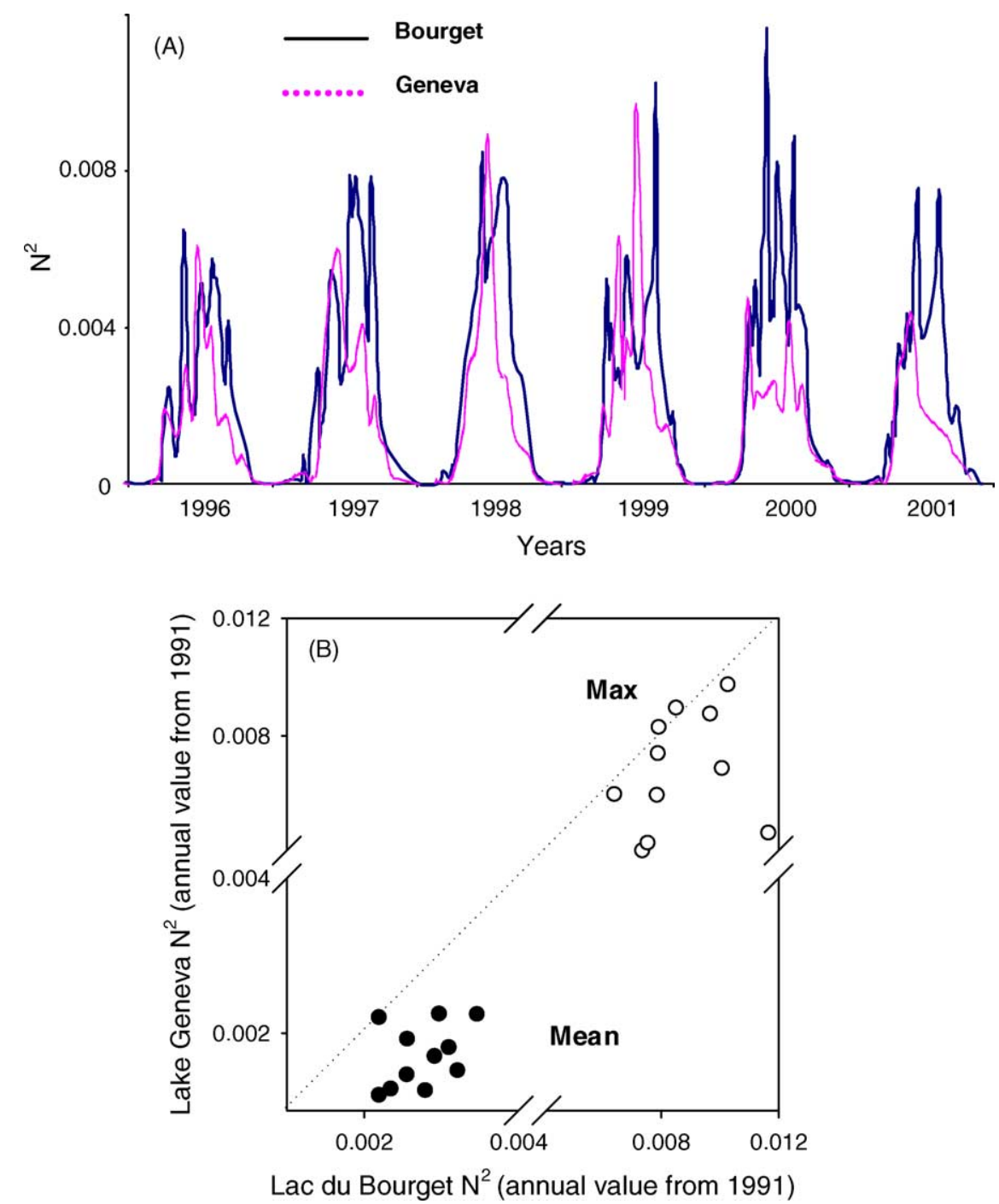

Fig. 7. A: Data sets obtained for the water column stability of Lac du Bourget and Lake Geneva between 1996 and 2001 , as inferred from the calculation of the Brunt-Väisälä stability frequency. B: Mean and maximum annual values of the Brunt-Väisälä stability frequency between 1991 and 2001 for the two lakes. 
ysis and Gymnodinium (e.g. Roelke and Buyukates, 2002; Kanoshina et al., 2003). The advantage is gained because phytoplankton species that are able to regulate their position in the water column are able to visit both nutrient-rich deeper water and irradiance-saturated shallower water (Smayda, 1997). In addition, phytoplankton experiencing a temperature gradient may be favored by having enhanced physiological characteristics, which are important for competition and thus bloom initiation. The cal-

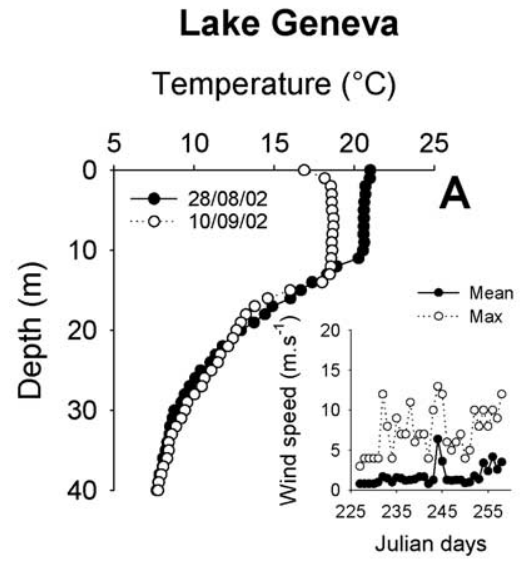

Eq. chl a conc. $\left(\mu \mathrm{g} . \mathrm{I}^{-1}\right)$

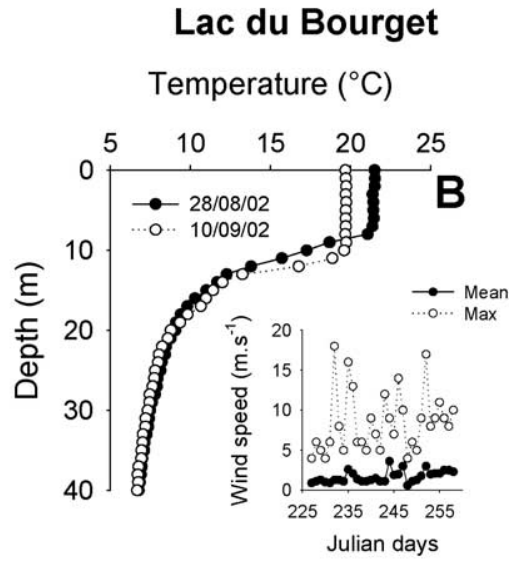

Eq. chl a conc. ( $\left.\mu \mathrm{g} \cdot \mathrm{I}^{-1}\right)$

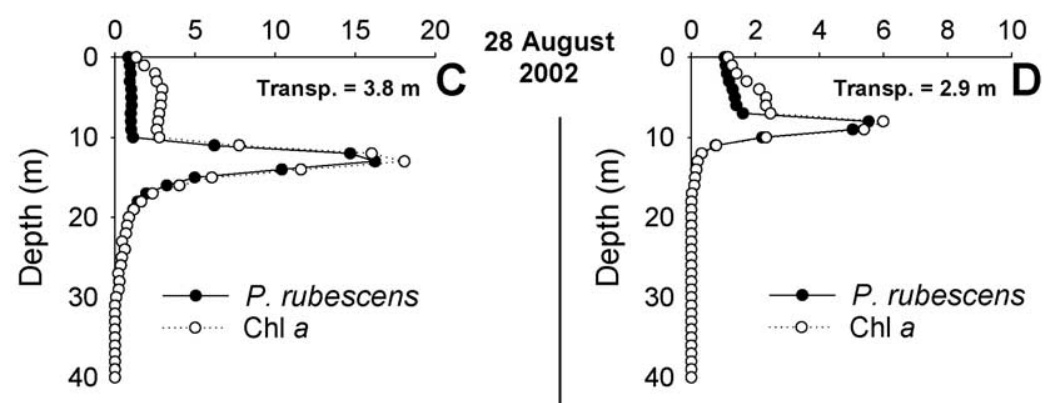

Eq. chl a conc. $\left(\mu \mathrm{g} . \mathrm{I}^{-1}\right)$

Eq. chl a conc. $\left(\mu \mathrm{g} . \mathrm{I}^{-1}\right)$

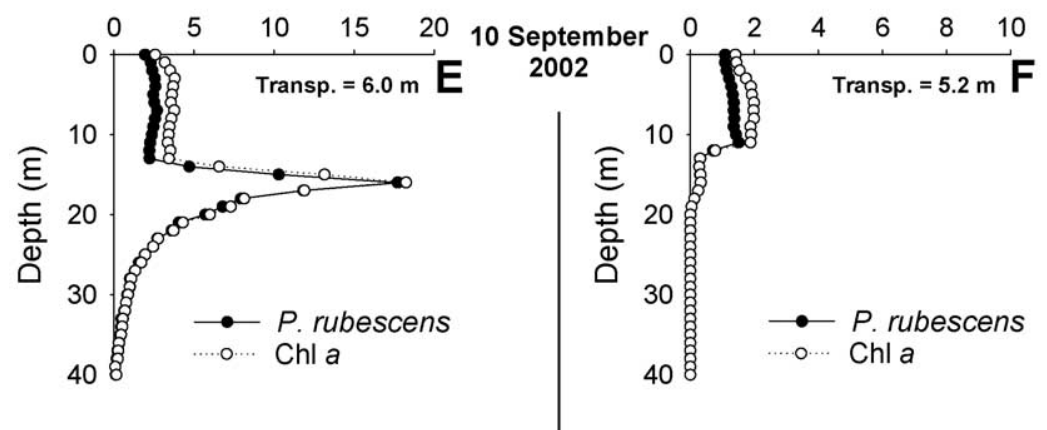

Fig. 8. Temperature, transparency and chlorophyll $a$ fluorescence profiles of P. rubescens on two selected days (28 August and 10 September 2002) in Lake Geneva and Lac du Bourget. Inserts correspond to the daily mean and maximum recorded values of wind speed for the two lakes. 
culation of the Brunt-Väisälä index over the last 10 years revealed indeed that the water column is clearly more stable in Lac du Bourget (Fig. 7). This is not surprising since the morphology of the Lake and its catchment translate into greater wind stress and fetch phenomena in Lake Geneva. Increased turbulence may lead to the cessation of stratification and thus negatively affect growth rates (e.g. Berdalet, 1992). The importance of the wind was demonstrated during the year 2002, when we observed a proliferation of $P$. rubescens in both lakes (Fig. 8). Strong wind during just 1 day in August led to a complete mixing of the population in the upper lit layers of Lac du Bourget, so that population growth was disrupted in the bloom. In contrast, no strong wind was recorded at this time in Lake Geneva, where the bloom persisted. Very interestingly, a similar pattern had been reported previously in Lake Zürich (Walsby and Schanz, 2002). One may argue that wind-induced mixing of nutrients from deeper waters into the euphotic zone could have stimulated $P$. rubescens, however the waters were in fact nutrient-depleted at this time.

Two hypotheses can therefore be proposed to explain the differing $P$. rubescens population dynamics in Lakes Geneva and Bourget. In Lac du Bourget, in response to increased transparency of the epilimnion, enough light reaches the population in spring and summer at $10-15 \mathrm{~m}$ depth, where, in addition, there is a possible input of nutrients from the hypolimnion (Etemad-Shahidi and Imberger, 2001). In contrast, in Lake Geneva, the limit between the epi- and the metalimnion is deeper in summer, and light conditions are clearly limiting for deep populations. This could also correspond to greater turbulence in the epilimnion of Lake Geneva and a less steep temperature gradient. This could also be crucial in terms of the critical pressure of gas vesicles in $P$. rubescens in relation to depth (Walsby et al., 1998). We postulated at the beginning of this section that the phytoplanktonic community was very similar in these two ecosystems. Mougeotia gracillima and Diatoma tenuis can represent $15 \%$ of the total community in summer and fall in Lake Geneva. As they are large filamentous species, they are poorly grazed, and can therefore proliferate in the near-surface waters. This could also be part of the explanation of why $P$. rubescens cannot develop at high cell concentration in the metalimnion of Lake Geneva as a result of light and nutrient limitations.

\section{Conclusion}

From our findings, it can be concluded that lake restoration (by nutrient control only) to prevent or remedy cyanobacterial occurrence and proliferation may need to be reconsidered depending on the phytoplanktonic community of the system studied. In Lac du Bourget, as in other meromictic lakes, blooms of P. rubescens have been reported in response to water quality restoration. More precisely, lower $\mathrm{P}$ levels in the surface layers of Lac du Bourget, combined with global warming, leading to milder winter and good spring and summer meteorological conditions in the second part of the 1990s, has allowed the emergence of the cyanobacterium $P$. rubescens as a result of the selection of an organism already present in the lake and well adapted to the new prevailing environmental conditions. Although this population may only be an intermediary/transitory response to the re-oligotrophication process, its toxicity is problematic, and the management and control of such blooms must be envisaged at a higher level of complexity. Successful attempts to control $P$. rubescens have been reported from all around the world. In the alpine Lake Bled, restoration has involved a combination of artificial inflow of clean water, removal of the hypolimnetic water and the diversion of treated sewage. This has resulted in the rapid disappearance of $P$. rubescens (Vrhovsek et al., 1985). The size of Lac du Bourget rules out this approach to restoration. The same can be said of any attempt to use artificial means to destabilize the water column. This has been attempted elsewhere in France for the colonial cyanobacterium Microcystis aeruginosa, without the hoped-for success (Latour et al., submitted). Minimizing the input of key nutrients, especially phosphorus, is a favored management tool and has often resulted in decreases in the frequency and intensity of algal blooms (e.g. O. rubescens in Lake Washington, Edmondson, 1991, in Lake Nantua, Feuillade, 1994). Mur and Schreurs (1995) showed that cyanobacterial blooms disappear below the threshold of $20 \mu \mathrm{g} \mathrm{P}^{-1}$. On the basis of data obtained from 99 temperate lakes, Downing et al. (2001) proposed that lake management for minimal risk of cyanobacteria dominance would require total $\mathrm{P}$ concentrations in the lake of less than $30 \mu \mathrm{g} \mathrm{Pl}^{-1}$. Chorus et al. (2001) reported that if total $\mathrm{P}$ concentrations (not only those of soluble $\mathrm{P}$ or orthophosphates) 
are below 10-20 $\mu \mathrm{g} \mathrm{P1}{ }^{-1}$, mass developments of cyanobacteria are unlikely to happen, and if high turbidity occurs, it may have other causes. In most bodies of water, the best way to minimize the risk due to toxic algae, is therefore to keep total $\mathrm{P}$ concentrations below $10 \mu \mathrm{g} \mathrm{Pl} l^{-1}$, keeping in mind this threshold concentration may be unrealistic to reach for many of these bodies. Cyanobacterial densities rarely reach hazardous levels even in water bodies containing up to $30 \mu \mathrm{gl}^{-1}$ total P. One good example is provided by Lake Mondsee, where restoration with $\mathrm{P}$ concentrations reaching values below $10 \mu \mathrm{g} \mathrm{Pl} 1^{-1}$ led to the disappearance of $P$. rubescens (Dokulil and Jagsch, 1992). A perfect example is also provided at a distance of less than $50 \mathrm{~km}$ from Lac du Bourget by the large alpine Lake Annecy, an oligotrophic ecosystem in which water quality has been monitored since the mid 1960s and where cyanobacterial blooms have never been detected. Clearly, the focus of remediation in large deep lakes like Lac du Bourget needs to be maintained on limiting external nutrient imputs, which in the long-term should reduce internal hypolimnetic sources and thus limit species such as $P$. rubescens.

\section{Acknowledgements}

We would like to acknowledge the contributions of Guy Barroin and Nadine Angeli in their critical reading and improvements of a draft version of this article. SJ would also like to thank Philippe Quétin, who allowed him access to some data concerning Lake Geneva (CIPEL database) and Brigitte LeBerre, who helped with sampling. This study was carried out with funding from le Comité Inter-Syndical du Lac du Bourget, l'Agence de l'eau Rhône-Méditerranée-Corse and le Ministère de l'Ecologie et du Développement Durable. English was checked by a specialist, Monica Ghosh. Anonymous reviewers are also acknowledged for their valuable comments on the submitted version.

\section{References}

AFNOR, 1982. Essais des eaux: norme française, dosage des orthophosphates, des polyphosphates et du phosphore total (méthode spectrométrique). NFT 90-023, AFNOR, 10 p.
Anagnostidis, K., Komarek, J., 1988. Modern approach to the classification system of cyanophytes. 3. Oscillatoriales. Arch. Hydrobiol. 80, 327-472.

Anneville, O., Pelletier, J.-P., 2000. Recovery of Lake Geneva from eutrophication: quantitative response of phytoplankton. Arch. Hydrobiol. 148, 607-624.

Anneville, O., Ginot, V., Druart, J.-C., Angeli, N., 2002. Long-term study (1974-1998) of seasonal changes in the phytoplankton in Lake Geneva: a multitable approach. J. Plank. Res. 24, 9931007.

Balland, P., 1976. Le lac du Bourget: exemple de lutte contre l'eutrophisation. CTGREF, Grenoble, pp. 323-340.

Berdalet, E., 1992. Effects of turbulence on the marine Dinoflagellate Gymnodinium nelsonii. J. Phycol. 28, 267-272.

Blom, J.-F., Robinson, J.A., Jüttner, F., 2001. High grazer toxicity of $\left[\mathrm{D}-\mathrm{Asp}^{3},(\mathrm{E})-\mathrm{Dhb}^{7}\right]$ microcystin-RR of Planktothrix rubescens as compared to different microcystins[D-Asp ${ }^{3}$, (E)-Dhb $\left.{ }^{7}\right]$ microcystin-RR of Planktothrix rubescens as compared to different microcystins. Toxicon 39, 1923-1932.

Bournet, P.-E., 1996. Contribution à l'étude hydrodynamique et thermique du lac du Bourget. Ph.D. thesis, Ecole Nationale du Génie Rural, des Eaux et des Forêts, Paris, 337 p.

Bournet, P.-E., Dartus, D., Tassin, B., Vinçon-Leite, B., 1999. Numerical investigation of plunging density currents. J. Hydraulic Eng. 125, 584-594.

Bourrelly, P., 1949. Deux cyanophycées nouvelles du lac du Bourget: Phormidium franqueti nov. sp. et Aphanocapsa farlowiana Drouet et Daily. Bull. Soc. Bot. Fr. 96, 231-232.

Bourrelly, P., 1955. Quelques pêches planctoniques dans le lac du Bourget et les lacs voisins. Verh. Int. Verein. Theor. Angew. Limnol. 12, 253-255.

Briand, J.-F., Jacquet, S., Bernard, C., Humbert, J.-F., 2003. Health hazards for terrestrial vertebrates from toxic cyanobacteria in surface water ecosystems. Vet. Res. 34, 1-17.

Bright, D.I., Walsby, A.E., 2000. The daily integral of growth by Planktothrix rubescens calculated from growth rate in culture and irradiance in lake Zurich. New Phytol. 146, 301-316.

Buergi, H.R., Stadelmann, P., 2000. Change of phytoplankton diversity during long-term restoration of lake Baldegg. Verh. Inter. Verein. Limnol. 27, 574-581.

Carmichael, W.W., 2001. Human fatalities from cyanobacteria: chemical and biological evidence for cyanotoxins. Environ. Health Perspect. 109, 663-668.

CEMAGREF, 1985. Le lac du Bourget (Savoie). Etude 1983. Technical Report, DQEP-CEMAGREF, Lyon, France, 123 p.

CEMAGREF, 1990. Le lac du Bourget (Savoie). Etude 1988-1989. Rapport de synthèse. Technical Report, DQEP-CEMAGREF, Lyon, France, 79 p.

CEREVE, 1998. Analyse de l'évolution de la qualité des eaux du lac du Bourget. 242 p.

Chorus, I., Bartram, J., 1999. Toxic Cyanobacteria in Water. Spon E \& FN, World Health Organization, London, 416 p.

Chorus, I., Falconer, I.R., Salas, H.J., Bartram, J., 2001. Health risks caused by freshwater cyanobacteria in recreational waters. J. Tox. Environ. Health 3, 323-347.

Davis, P.A., Dent, M., Parker, J., Reynolds, C.S., Walsby, A.E., 2003. The annual cycle of growth rate and biomass change in 
Planktothrix spp. in Blelhalm tarn, English lake district. Fresh. Biol. 48, 852-867.

Dokulil, M.T., Jagsch, A., 1992. The effects of reduced phosphorus and nitrogen loading on phytoplankton in Mondsee, Austria. Hydrobiology 243-244, 389-394.

Dokulil, M.T., Teubner, K., 2000. Cyanobacterial dominance in lakes. Hydrobiolgy 438, 1-12.

Downing, J.A., Watson, S.B., McCauley, E., 2001. Predicting cyanobacteria dominance in lakes. Can. J. Fish Aquat. Sci. 58, 1905-1908.

Edmondson, W.T., 1991. The Uses of Ecology: Lake Washington and Beyond, Washington University Press, Seattle, 329 pp.

Etemad-Shahidi, A., Imberger, J., 2001. Anatomy of turbulence in thermally stratified lakes. Limnol. Oceanogr. 46, 1158-1170.

Fastner, J., Erhard, M., Carmichael, W.W., Sun, F., Rinehart, K.L., Rönicke, H., Chorus, I., 1999. Characterization and diversity of microcystins in natural blooms and strains of the genera Microcystis and Planktothrix from German freshwaters. Arch. Hydrobiol. 145, 147-163.

Feuillade, J., 1994. The cyanobacterium (blue-green algae) Oscillatoria rubescens D.C. Arch. Hydrobiol. Beih. Eregbn. Limnol. 41, 77-93.

Feuillade, M., Druart, J.-C., 1994. The long-term effect of the sewage diversion on the phytoplankton composition and biomass. Arch. Hydrobiol. Beih. 41, 55-76.

Feuillade, M., Feuillade, J., Blanc, P., 1990. Alkaline phosphatase activity fluctuations and associated factors in a eutrophic lake dominated by Oscillatoria rubescens. Hydrobiology 207, 233240.

Groleau, A., Sarazin, G., Vinçon-Leite, B., Tassin, B., QuiblierLloberas, C., 2000. Tracing calcite precipitation with specific conductance in a hard water Alpine Lake (Lake Bourget). Water Res. 34, 4151-4160.

Harris, G.P., 1986. Phytoplankton Ecology, Structure, Function and Fluctuation. Chapman \& Hall, New York.

Hodges, B.R., Imberger, J., Saggio, A., Winters, K.B., 2000. Modeling basin-scale internal waves in a stratified lake. Limnol. Oceanogr. 45, 1603-1620.

Hubault, E., 1943. Les grands lacs subalpins de Savoie sont-ils alcalinotrophes ? Arch. Hydrobiol. 40, 1.

Hubaut, E., 1947. Etudes thermiques, chimiques et biologiques des eaux des lacs de l'est de la France (Vosges, Jura, Alpes de Savoie). Ann. Ecol. Nat. Eaux et Forêts 10.

Humbert, J.-F., Paolini, G., Le Berre B., 2001. Monitoring a toxic cyanobacterial bloom in Lake Bourget (France) and its consequences for water quality. In: Hallegraeff, et al. (Eds), Harmful Algal Bloom 2000, Intergovernmental Oceanographic Commission of UNESCO 2001, pp. 496-499.

Hurrel, J.W., 1995. Decadal trends in the North Atlantic oscillation: regional temperatures and precipitation. Science 269, 676-679.

Jochimsen, E.M., 1998. Liver failure and death after exposure to microcystins at a haemodialysis centre in Brazil. New Eng. J. Med. 338, 873-878.

Kanoshina, I., Lips, U., Leppänen, J.-H., 2003. The influence of weather conditions (temperature and wind) on cyanobacterial bloom development in the Gulf of Finland (Baltic Sea). Harmful Algae 2, 29-41.
Kromkamp, J., Walsby, A.E., 1990. A computer model of buoyancy and vertical migration in cyanobacteria. J. Plank. Res. 12, 161183.

Kurmayer, R., Juttner, F., 1999. Strategies for the co-existence of zooplankton with the toxic cyanobacterium Planktothrix rubescens in Lake Zurich. J. Plank. Res. 21, 659-683.

Laurent, P.J., 1966. Modifications biologiques récentes dans quelques lacs subalpins. Extrait du Bulletin de l'Association Romande pour la Protection des Eaux et de l'Air 18, 47-56.

Latour, D., Giraudet, H., Berthon, J.-L., Influential parameters on the spatio-temporal distribution of benthic and planktonic cyanobacteria in the hypereutrophic Grangent reservoir (Loire). Comptes Rendus Acad. Sci. (submitted for publication).

Leboulanger, C., Dorigo, U., Jacquet, S., LeBerre, B., Paolini, G., Humbert, J.-F., 2002. Application of a submersible spectrofluorometer for rapid monitoring of freshwater cyanobacterial blooms: a case study. Aquat. Microb. Ecol. 30, 83-89.

Lemmin, U., 1978. Lakes, Chemistry, Geology, Physics. Springer Verlag, $363 \mathrm{p}$.

Leroux, M., 1928. Recherches biologiques dans les grands lacs de Savoie, lac du Bourget et d'Annecy (Annecy), 6 p.

Matsunaga, H., Harada, K.-I., Senna, M., Ito, Y., Yasuda, N., Ushida, S., Kimura, Y., 1999. Possible cause of unnatural mass death of wild birds in a pond in Nishinomiya, Japan: sudden appearance of toxic cyanobacteria. Nat. Tox. 7, 81-84.

Mez, K., Beattie, K.A., Codd, G.A., Hanselman, K., Hauser, B., Naegeli, H., Preisig, H.R., 1997. Identification of a microcystin in benthic cyanobacteria linked to cattle deaths on alpine pastures in Switzerland. Eur. J. Phycol. 32, 111-117.

Micheletti, S., Schanz, F., Walsby, A.E., 1998. The daily integral of photosynthesis by Planktothrix rubescens during summer stratification and autumnal mixing in Lake Zürich. New Phytol. 138, 233-249.

Mur, L.R., Schreurs, H., 1995. Light as a selective factor in the distribution of phytoplankton species. Water Sci. Tech. 32, 25-34.

Nehring, S., 1993. Mortality of dogs associated with a mass development of Nodularia spumigena (Cyanophyceae) in a brackish lake at the German North Sea coast. J. Plank. Res. 15, 867-872.

OECD, 1982. Eutrophication of Waters. Monitoring, Assessment and Control. OECD, Paris, $154 \mathrm{p}$.

Olivier, R.L., Ganf, G.G., 2000. Freshwater blooms. In: Whitton, B.A., Potts, M. (Eds.), The Ecology of Cyanobacteria: Their Diversity in Time and Space. Kluwer Academic Publishers, London, pp. 149-194.

Omlin, M., Reichert, P., Forster, R., 2001. Biogeochemical model of Lake Zürich: model equations and results. Ecol. Model. 141, 77-103.

Padisak, J., Reynolds, C.S., Sommer, U., 1993. Intermediate disturbance hypothesis in phytoplankton ecology. Aquat. Bot. 51, 341-342.

Raven, J.A., 1984. A cost-benefit analysis of photon absorption by photosynthetic unicells. New Phytol. 98, 593-625.

Reynolds, C.S., 1980. Phytoplankton assemblages and their periodicity in stratifying lake systems. Holartic Ecol. 3, 141159. 
Reynolds, C.S., 1987. Cyanobacterial water blooms. In: Callow, J.A. (Ed.), Advances in Botanical Research, vol. 13. Academic Press, pp. 67-143.

Reynolds, C.S., Walsby, A.E., 1975. Water blooms. Biolog. Rev. 50, 437-481.

Reynolds, C.S., Oliver, R.L., Walsby, A.E., 1987. Cyanobacterial dominance: the role of buoyancy regulation in dynamic lake environments. N. Z. J. Mar. Fresh Res. 21, 379-390.

Reynolds, C., Huszar, V., Kruk, C., Naselli-Flores, L., Melo, S., 2002. Towards a functional classification of the freshwater phytoplankton. J. Plank. Res. 24, 417-428.

Rocha, C., Galvao, H., Barbosa, A., 2002. Role of transient silicon limitation in the development of cyanobacteria blooms in the Guadiana estuary, south-western Iberia. Mar. Ecol. Progr. Ser. 228, 35-45.

Rodger, H.D., Turnbull, T., Edwards, C., Codd, G.A., 1994. Cyanobacterial (blue-green algal) bloom associated pathology in brown trout, Salmo trutta L., in Loch Leven, Scotland. J. Fish Dis. 17, 177-181.

Roelke, D., Buyukates, Y., 2002. The diversity of harmful alga bloom-triggering mechanisms and the complexity of bloom initiation. Hum. Ecol. Risk Assess. 7, 1347-1362.

Salmaso, N., 1996. Seasonal variation in the composition and rate of change of the phytoplankton community in a deep subalpine lake (Lake Garda, northern Italy). An application of nonmetric multidimensional scaling and cluster analysis. Hydrobiology 337, 49-68.

Salmaso, N., 2000. Factors affecting the seasonality and distribution of cyanobacteria and chlorophytes: a case study from the large lakes south of the Alps, with special reference to Lake Garda. Hydrobiology 438, 43-63.

Sas, H., 1989. Lake Restoration by Reduction of Nutrients Loading: Expectations, Experiences, Extrapolations. Academia Verlag Richarz, St. Augustin, Germany.

Sheffer, M., Straile, D., van Nes, E.H., Hosper, H., 2001. Climatic warming causes shifts in lake food webs. Limnol. Oceanogr. 46, 1780-1783.

Sheridan, C.C., Steinberg, D.K., Kling, G.W., 2002. The microbial and metazoan community associated with colonies of Trichodesmium spp.: a quantitative survey. J. Plank. Res. 24, 913-922.

Smayda, T.J., 1997. Harmful algal blooms: their ecophysiology and general relevance to phytoplankton blooms in the sea. Limnol. Oceanogr. 42, 1137-1153.

Straile, D., 2000. Meteorological forcing of plankton dynamics in a large and deep continental European lake. Oecologia 122, 44-50.

Straile, D., Adrian, R., 2000. The North Atlantic oscillation and plankton dynamics in two european lakes: two variations on a general theme. Global Change Biol. 6, 1-8.

Strickland, J.D.H., Parsons T.R., 1972. A Practical Handbook of Seawater Analysis, vol. 167, second ed. Bull. Fish. Res. Bd., Canada, $311 \mathrm{pp}$.

Suttle, C. A., 2000. Cyanophages and their role in the ecology of cyanobacteria. In: Whitton, B.A., Potts, M. (Eds.), The Ecology of Cyanobacteria: Their Diversity in Time and Space. Kluwer Academic Publishers, London, pp. 563-589.

Tassin, B., Vinçon-Leite, B., 1998. Forecasting of water quality in lakes: a predictive use of one-dimensional model. Application to lake (Bourget Savoie), France. Hydrobiology 373-374, 4760 .

Thorpe, S.A., 1997. On the interactions of internal waves reflecting from slopes. J. Phys. Oceanogr. 27, 2072-2078.

Uthermöhl, H., 1958. Zur Vervollkommung der quantitativen phytoplankton-methodik. Mitt. Int. Ver. Limnol. 9, 38.

Utkilen, H.C., Oliver, R.L., Walsby, A.E., 1985. Buoyancy regulation in a red Oscillatoria unable to collapse gas vacuoles by turgor pressure. Arch. Hydrobiol. 102, 319-329.

Vaughan, I.P., Davis, P.A., Walsby, A.E., 2001. Changes in the photosynthetic coefficients $\alpha$ and $P_{\mathrm{m}}$ of Planktothrix rubescens grown on light-dark cycles. Aquat. Sci. 63, 350-362.

Vinçon-Leite, B., 1991. Contribution de la modélisation mathématique à l'étude de la qualité de l'eau dans les lacs sub-alpins: le lac du Bourget. Ph.D. Thesis, Ecole Nationale des Ponts et Chaussées, Paris, 274 p.

Vinçon-Leite, B., Mouchel, J.-M., Tassin, B., 1989. Modélisation de l'évolution thermique saisonnière du lac du Bourget (Savoie, France). Revue des Sciences de l'Eau 2, 483-510.

Vinçon-Leite, B., Tassin, B., Jaquet, J.-M., 1995. Contribution of mathematical modeling to lake ecosystem understanding: Lake Bourget (Savoy, France). Hydrobiology 300-301, 433442.

Vinçon-Leite, B., Tassin, B., Druart, J.-C., 2002. Phytoplankton variability in Lake Bourget: phytoplankton dynamics and meteorology. Lakes Reservoirs Res. Manage. 7, 93102.

Vrhovsek, D., Kosi, G., Kralj, M., Bricelj, M., Zupan, M., 1985. The effect of lake restoration measures on the physical, chemical and phytoplankton variables of Lake Bled. Hydrobiology 1127, 219-228.

Walsby, A.E., Schanz, F., 2002. Light-dependent growth rate determines changes in the population of Planktothrix rubescens over the annual cycle in Lake Zürich, Switzerland. New Phytol. 154, 671-687.

Walsby, A.E., Avery, A., Schanz, F., 1998. The critical pressures of gas vesicles in Planktothrix rubescens in relation to the depth of winter mixing in Lake Zürich, Switzerland. J. Plank. Res. 20, 1357-1375.

Walsby, A.E., Dubinsky, Z., Kromkamp, J.C., Lehmann, C., Schanz, F., 2001. The effects of diel changes in photosynthetic coefficients and depth of Planktothrix rubescens on the daily integral of photosynthesis in Lake Zurich. Aquat. Sci. 63, 326349.

Weyhenmeyer, G.A., Blenckner, T., Petterson, K., 1999. Changes of the plankton spring outburst related to the North Atlantic oscillation. Limnol. Oceanogr. 44, 1788-1792.

Zotina, T., Kosher, O., Jüttner, F., 2003. Photoheterotrophy and light-dependent uptake of organic and organic nitrogenous compounds by Planktothrix rubescens under low irradiance. Fresh Biol. 48, 1859-1872. 